\title{
INCOMPLETUDE DAS INFORMAÇÕES NA 11.101/05: UMA ABORDAGEM MEDIANTE ANÁLISE ECONÔMICA DO DIREITO
}

\author{
INCOMPLETUATION OF INFORMATION 11.101 / 05: AN \\ APPROACH THROUGH AN ECONOMIC ANALYSIS OF THE LAW
}

\author{
HeNRIQUe AVELINO LANA* \\ Eduardo Goulart Pimenta *"
}

\section{RESUMO}

Pretende-se neste trabalho, via Análise Econômica do Direito, identificar, de forma construtiva, que a atual redação da Lei 11.101/05 enseja assimetria de informações, o que contribui para a sua ineficiência. A metodologia a ser utilizada é de método dedutivo, mediante abordagem explicativa e descritiva, além de pesquisa bibliográfica. Inicialmente será feita uma contextualização do tema, mediante abordagem dos princípios da função social e preservação da empresa. Após, serão identificados os aspectos existentes na Lei de Recuperação de Empresas e Falência que permitem afirmar que há, sim, forte ensejo à assimetria de informações.

PALAVRAS-CHAVE: Recuperação de empresas. Falência. Assimetria de Informações.

\begin{abstract}
This work, through Economic Analysis of Law, aims to constructively identify the current wording of Law 11.101 / 05 asymmetry of information, which contributes to its inefficiency. The methodology to be used is a deductive method, through an explanatory and descriptive approach, as well as bibliographic research. Initially a contextualization of the theme will be made, by approaching the principles of social function and preservation of the company. Afterwards, the aspects in the Law on Corporate Recovery and Bankruptcy will be identified, which allow us to affirm that there is a strong opportunity to asymmetry of information.
\end{abstract}

KEYWORDS: Recovery of companies. Bankruptcy. Asymmetry of Information.

\section{INTRODUÇÃO}

Passada mais de uma década desde a entrada em vigência da Lei 11.101/05(Lei de Recuperação de Empresas e Falência) acredita-se que, academicamente, seja possível se fazer uma análise em relação a sua eficiência e objetivos alcançados. (BRASIL, 2005). A recuperação é importante instrumento e mecanismo legal, está presente no dia a dia da sociedade em geral, empresas, empresários e sócios da sociedade empresária, sobretudo no recente contexto de notória crise econômica interna no Brasil.

A antiga concordata, prevista do Decreto Lei 7.661/45, ao longo de cerca de 60 anos, revelou-se insuficiente a possibilitar uma solução eficiente para

\footnotetext{
* Pós Doutorando, Doutor, Mestre e Especialista em direito pela PUC/MG. Professor na PUC/ MG e na UMA/MG. E-mail: henrique@mpaladvogados.com.br.

* Doutor e Mestre pela Universidade Federal de Minas Gerais. Professor na UFMG e na PUC/ MG.E-mail: goulartpimenta@direito.ufmg.br.
} 
o soerguimente das atividades empresariais em crise econômica, financeira e patrimonial, sobretudo ante a ausência de cooperação e intervenção adequada por parte dos credores e demais pessoas, cujos interesses, sociais e econômicos, gravitam sobre a atividade negocial. (BRASIL, 1945). Verifica-se que o atual contexto social e econômico de nosso país, por si, já impõe severas adversidades ao sucesso do empresário quando do exercício de sua atividade, tais como alta carga tributária, concorrência antiética e ônus advindos da legislação do trabalho. O tema objeto deste trabalho se justifica, dada a sua cada vez maior presença no dia a dia do empresário. Em tese, traria a Lei 11.101/05 novo remédio destinado a viabilizar a superação da crise, mediante melhor negociação entre credores e devedor empresário, de modo a se evitar a declaração de falência. Sabe-se que quanto maiores, numerosas, contínuas, duradouras e tranquilo for o exercício das atividades econômicas, maior será o fomento para a dinamização da economia de nosso país, com geração de mais empregos, recolhimento de mais tributos e acumulação de mais parceiros comerciais.

O tema surgiu a partir da exposição de aulas nos cursos de graduação, em que, após o primeiro contato do aprendizado pelos alunos, vários chegavam à conclusão de que, infelizmente, a "lei de recuperação não funciona". Assim, o problema levantado neste trabalho é, via análise Econômica do Direito, identificar aspectos da lei 11.101/05 que merecem ser ajustados para que seja reduzida a assimetria de informações, contribuindo-se para sua maior eficiência. A metodologia a ser utilizada é de método dedutivo, mediante abordagem explicativa e descritiva, além de pesquisa bibliográfica.

\section{A EMPRESA EM CRISE ECONÔMICA, FINANCEIRA E PATRI- MONIAL.}

Resultado de uma sociedade baseada em um sistema de produção capitalista, grande parte da população brasileira encontra a satisfação de suas necessidades e desejos nos frutos das atividades empresariais e negociais. Seja para obtenção de produtos e serviços relacionados à subsistência, seja para satisfazer os anseios do lazer e do consumismo, seja ainda como fonte de renda, as atividades empresariais têm influência diária na vida de todos os indivíduos. As empresas desenvolvem-se com o objetivo de produzir bens e serviços que atendam a demanda da população e, como resultado, lhes proporcione auferir lucros, o ideal perseguido no modelo capitalista de produção. No intuito de ver prosperar seus rendimentos, as empresas buscam um aumento de produção baseado na especialização do mercado, o que exige uma grande interconexão dos diferentes segmentos, a fim de produzirem-se, em maior escala, os produtos e serviços, cada vez mais.

A crise econômica e financeira de uma empresa, por trazer efeitos para toda a sociedade, é alvo de preocupação do Estado, e o leva a introduzir mecanismos 
que possam amenizar suas consequências. Assim, o Estado cria normas para regular o procedimento para empresas em crise, visando à satisfação de seus credores, sejam eles trabalhadores, os fornecedores e a própria comunidade em que a empresa se encontra inserida, os quais confiaram no desenvolvimento de uma atividade que não teve êxito e adentrou em crise. No Brasil, os interesses em conflitos decorrentes da crise econômico-financeira de uma empresa são tutelados pela Lei $n^{\circ} 11.101 / 05$, que é a Lei de Recuperação de Empresas e Falência (LREF), a qual estabelece os mecanismos de recuperação de empresas, para as hipóteses em que seja constatado que a crise é contornável e superável, e da falência, consistente na execução coletiva dos débitos para os casos em que a recuperação da empresa não seja mais viável.

A partir da leitura de seus dispositivos, verifica-se que o objetivo da lei é proporcionar a satisfação dos credores e, ao mesmo tempo, a preservação da unidade produtiva viável, introduzindo mecanismos para otimizar os recursos empresariais, ou, então, a distribuição proporcional entre os credores dos eventuais prejuízos decorrentes da quebra do devedor. O exercício da atividade empresarial pressupõe a existência de diversos contratos, tais como, exemplificativamente, de aluguel, os contratos trabalhistas, prestação de arte gráfica de marcas e embalagens, preservação dos equipamentos necessários ao exercício da atividade empresarial, financiamentos e empréstimos bancários para aquisição de equipamentos e matérias-primas, além de obrigações legais, tais como as obrigações tributárias.

Revela-se a crise econômico-financeira de uma empresa, que acarreta o processo de falência ou autofalência, quando, em síntese, há a impossibilidade financeira da empresa manter-se adimplente com todos os seus credores. Há pelo procedimento falimentar o objetivo de proteger o crédito e evitar que a crise de uma empresa acarrete efeitos drásticos sobre sua rede de credores, fornecedores e parceiros comerciais. Em observância aos reclamos da sociedade, o processo falimentar e recuperacional do direito brasileiro teria sofrido, em tese, substanciais modificações, após a revogação do Decreto Lei 7.661/45.

A Lei $n^{\circ} 11.101 / 2005$, que disciplina a recuperação judicial, a recuperação extrajudicial e a falência do empresário e da sociedade empresária, modificou profundamente o regime falimentar nacional. O Decreto-Lei n ${ }^{\circ} 7.661 / 1945$ não acompanhou as transformações do cenário econômico, empresarial e falimentar. Assim, a antiga norma não ajudava os credores que não conseguiam receber os créditos e também não atendia o devedor que via o patrimônio que restava da sua atividade empresarial deteriorar-se em processos morosos (GONÇALVES; ALMEDANHA, 2013, p. 4).

Isso, pois havia a necessidade de se perseguir objetivos mais abrangentes, quais sejam, tentar conciliar a satisfação do crédito, a preservação da atividade empresarial, juntamente com a otimização dos recursos empresariais 
produtivos. E tal propósito e reclamos da sociedade sustentavam-se no fato de que a satisfação dos credores, na maior parte dos procedimentos de falência, não é alcançada apenas com a liquidação do patrimônio da empresa devedora. A realidade de fato vivenciada por todos os atores do processo de falência, sejam eles credores ou devedores, leva ao raciocínio de que é imperioso adotar mecanismos de harmonização dos elementos da empresa em crise, com o fim de otimizar a satisfação de todos os interesses e servir como um instrumento eficaz de estímulo à atividade econômica.

É indiscutível a evolução implementada pela nova legislação. Entretanto, seria humanamente impossível que tamanho desenvolvimento, no que tange ao salto evolutivo nas disposições do Direito Falimentar brasileiro, fosse capaz de abarcar, de uma só vez, todas as possibilidades de aplicação à matéria de fato. Desta feita, surge a necessidade de que tal texto de lei permaneça em revisão, a fim de que continue evoluindo durante a sua vigência, adequando-se às novas realidades sociais e redefinindo seu universo de incidência (BANDO, 2014, p.2).

Importante inovação da Lei 11.101/05 foi promover a introdução de um mecanismo de recuperação de empresas, a exemplo do sistema adotado pelo ordenamento da França e da Itália, que tem como objetivo preservar a empresa, a fonte produtora de emprego, servindo de estímulo à atividade econômica, nos termos de seu artigo 47. Neste diploma normativo, criou-se uma nova figura, da recuperação judicial, em substituição à antiga concordata. Esse novo instituto teve como mote principal a preocupação do legislador em possibilitar a recuperação efetiva da empresa. A norma jurídica passou a reconhecer, especificamente no art. 47 da Lei 11.101/2005, o interesse social em garantir instrumentos para que empresas temporariamente em crise possam se recuperar (GUIMARÃES; BORDA, 2015, p. 21).

É salutar a contribuição para o direito empresarial e para toda a sociedade, o surgimento de uma legislação que não mais considera a crise empresarial como um fato suscetível de punição, mas sim uma situação indesejada e que mereça uma tutela legal própria, a fim de realizar-se o objetivo constitucional de promover o desenvolvimento nacional e regional. O progresso trouxe consigo o entendimento de que a falência não deveria mais ser considerada um delito, mas uma das consequências inerentes ao risco do negócio que, em momentos de crise econômica, pode atingir qualquer empresário, por mais experiente e cauteloso que seja (BANDO, 2014, p. 2). Em tese, a recuperação judicial seria o instituto jurídico fundado na ética da solidariedade, para sanar o estado de crise econômico-financeira do empresário e da sociedade empresária, para preservar os negócios sociais e estimular a atividade empresarial, assegurar a continuidade do emprego e fomentar o trabalho humano, continuar a satisfação, mesmo que 
parcial e em diferentes condições e proporções, dos direitos e interesses dos credores, além de impulsionar a economia creditícia, mediante a apresentação, nos autos da recuperação judicial, de um plano de reestruturação e reerguimento.

A LREF sustenta-se em quatro princípios basilares: a supremacia da recuperação da empresa sobre o interesse do sujeito da atividadeacarretando,com efeito, o possível afastamento dos administradores da empresa; a manutenção da fonte produtora de riqueza e de emprego - impedindo a alienação em separado dos bens; o incentivo à manutenção de meios produtivos à empresa; e a manutenção dos interesses dos credores, com a participação efetiva destes em todo o transcurso do processo de recuperação. (NEGRÃO, 2012, p. 159) ${ }^{1}$

Em tese, se não houver demonstração de viabilidade de crescimento e interesse social, a crise econômico-financeira de uma empresa não terá outro destino diferente da falência. Mesmo tratando-se de hipótese de falência, a Lei 11.101/05 introduziu a necessidade da preservação da unidade produtiva mesmo enquanto tramita o processo. ${ }^{2}$ Nota-se que a liquidação total da empresa não é atualmente o foco central do procedimento falimentar, e sim a preservação, bem como a otimização dos recursos produtivos. ${ }^{3}$

Embora a LREF continue a estabelecer um procedimento de execução coletiva, de modo que todos os credores da empresa em crise tenham seus interesses resguardados de forma harmônica, garantindo-se a par conditio creditorum, acrescenta em sua finalidade também a preservação da empresa, ainda que sob o ponto de vista da otimização produtiva dos bens da empresa (SONAGLI; GONÇALVES, 2014).

Diante da importância da manutenção da empresa, enquanto atividade econômica, já há muito se vem invocando o princípio de sua preservação, de modo a se evitar o fim da produção ou circulação dos bens e serviços proporcionada por determinada sociedade empresária. O novo sistema é calcado no princípio da preservação da empresa, tanto na recuperação quanto

1 Fábio Ulhoa Coelho (2013, p. 404-405) ressalva, contudo, que a reorganização da atividade econômica é um procedimento custoso, que envolve risco para os credores, e que, constatandose que na grande maioria dos casos os agentes econômicos do país, instituições financeiras, são os maiores credores, os ônus associados aos riscos da recuperação acabam sendo suportados por toda a sociedade com o aumento dos custos dos serviços bancários.

2 Lei 11.101/05 - Art. 75. A falência, ao promover o afastamento do devedor de suas atividades, visa a preservar e otimizar a utilização produtiva dos bens, ativos e recursos produtivos, inclusive os intangíveis, da empresa. Parágrafo único. O processo de falência atenderá aos princípios da celeridade e da economia processual.

3 Vislumbra-se, portanto, que no atual contexto, impera o fundamento de preservação da atividade empresarial e a necessidade de inovação no procedimento de gestão da massa e da atividade da empresa em dificuldade, para que os credores possam acreditar no procedimento e fomentar suas atividades com a massa, incrementando valor aos bens arrecadados, para, ao final, proporcionar a realização do passivo no seu todo ou em parte, afinal, a realidade demonstra que a falência comumente não consegue satisfazer a totalidade dos credores, com o esgotamento do patrimônio muito antes de isso ocorrer. Compreendida a função socioeconômica e os fins reais sobre os quais repousa a LREF [...] (SONAGLI; GONÇALVES, 2014). 
na falência, embora sob ângulos diferentes. Enquanto na primeira o objetivo é permitir que o empresário retome suas atividades regularmente depois de superada sua crise, na segunda o princípio destina-se à otimização dos ativos destinando-os a outros empresários que possam conferir a devida utilidade gerando mais empregos e tributos, por exemplo. Com isso espera-se beneficiar credores, o devedor, os trabalhadores e a sociedade em seu todo (GONÇALVES; ALMEDANHA, 2013, p. 5).

As empresas comerciais representam um valor econômico de organização que é necessário conservar, para salvaguarda do esforço organizador dos empresários, do direito dos empregados ao trabalho, dos direitos dos sócios a ver frutificar seu capital (NUNES, 2001, p. 58). O fato é que a LRF destinase a preservar e manter no mercado a empresa, esta considerada como fonte produtora, como geradora de emprego e renda, e, por conseguinte, como um importante instrumento de desenvolvimento econômico e social. Tanto é assim que o art. 47 da Lei $n^{\circ}$ 11.101/2005 aponta como escopo da lei a viabilização da superação da crise econômico-financeira, a fim de permitir a preservação da empresa, sua função social e o estímulo à atividade econômica (GONÇALVES; ALMEDANHA, 2013, p. 9). A empresa, seja macro, média, pequena ou micro, como instituição fundamental de nossa época, há de ser preservada, tanto que possível, mesmo que, para isso, tenha-se de contrapor o hoje denominado "princípio preservativo da empresa" ao interesse individual do sócio e às anacrônicas regras de um vetusto Código (LUCENA, 1996).

Com o princípio da preservação da empresa, almeja-se impor a continuação da atividade, evitando-se seu encerramento, tendo em vista as repercussões econômicas positivas que a manutenção da atividade acarreta a terceiros. O princípio da preservação da empresa constitui-se na imposição de determinadas normas e condutas ao empresário e àqueles que diretamente estão envolvidos com a empresa, tendentes a possibilitar ao organismo econômico cumprir com a demanda social em torno de si mesmo à custa do interesse de seus titulares. (PIMENTA, 2004a, p. 34). Todavia, ao consultar o texto da Constituição nota-se que não há qualquer previsão explícita a um princípio de preservação da empresa que seja indicativo do dever do Estado dispensar especial tratamento a empresas em dificuldades financeiras. O que há são os princípios da ordem econômica que protegem a valorização do trabalho e a liberdade de iniciativa como elementos fundamentais de nossa ordem econômica (GUIMARÃES; BORDA, 2015).

A Lei de Recuperação e Falências, atualmente vigente em nosso país, tem como preceito fundamental a manutenção da empresa e dos seus recursos produtivos, conferindo-lhes a possibilidade de se reestruturar, conservando os empregos de seus funcionários e cumprindo a sua função social (BANDO, 2014). Desta forma, os interesses que gravitavam em torno da empresa: os 
trabalhadores, fornecedores, prestadores de serviços e a própria comunidade, que são atingidos pela crise da empresa, passaram a ser reconhecidos e tutelados pelo Poder Público, que assumiu, portanto, papel de relevância na solução do conflito, buscando a recuperação da empresa e a manutenção da atividade empresarial. Tal situação propiciou um nítido deslocamento da matéria, antes de cunho eminentemente privatístico, para o campo publicístico. O Estado passou a tutelar os interesses coletivos, reconhecendo a imprescindível função social que a empresa tem na sociedade contemporânea, tornando possível a introdução no direito concursal do instituto da recuperação de empresas (GUIMARÃES, 2007a, p. 268). ${ }^{4}$ Entretanto, não foi sempre assim. Nos primórdios da humanidade, buscava-se exclusivamente a satisfação dos credores, mesmo que para isso fosse necessário se utilizar de mecanismos coercitivos de caráter pessoal impostos sem se observar direito algum de defesa. $\mathrm{Na}$ fase mais primitiva, onde não existia intervenção do Estado, a justiça era feita com as próprias mãos e os interesses do credor é que comandavam a execução, ainda que a satisfação desses interesses atingissem a liberdade, a saúde ou, até mesmo, a vida dos devedores (BANDO, 2014).

Já se aproximando do direito moderno, essas ações eram constituídas por atos públicos, para que os outros credores também pudessem concorrer, e as provas deveriam ser produzidas pela parte que alegasse o direito, sendo estas de livre valoração do juiz. Se nem sob a administração do curador as dívidas fossem solvidas, os bens podiam ser alienados pela melhor oferta e o valor arrecadado eram rateados proporcionalmente a todos os credores habilitados (BANDO, 2014). Com a atividade econômica da sociedade empresária em funcionamento, fomenta-se a economia do país, proporcionando-se acúmulo de parceiros comerciais, clientes e prestadores de serviços, mais empregos são gerados, mais tributos são recolhidos, etc. Enquanto atividade, a empresa acarreta interesses não só dos titulares do empreendimento, mas também da comunidade em geral e do próprio poder público. De fato, a Constituição Federal Brasileira, que trata o Estado como agente econômico, invoca a necessidade de se buscar a justiça social.

Especificamente em nosso ordenamento, o interesse social na moderna empresa privada, dentro de uma ordem econômica fundada na liberdade de iniciativa (art. 170 da Constituição Federal de 1988, caput), vem se tornando cada vez mais premente, em especial em um contexto onde a presença do Estado como agente econômico está diminuindo, ao mesmo tempo em que aumenta a preocupação com a realização dos ditames da justiça social (art. 170 da Constituição Federal de 1988, caput). (PIMENTA, 2004a, p. 30).

4 Sobre detalhada evolução histórica, ver em: Guimarães, Maria Celeste Morais. Entraves à eficácia da Lei de recuperação de empresas em crise. Como superá-los? p. 265-280 (GUIMARÃES, 2007a, p. 265-280). 
Afinal, a atividade empresária açambarca em seu funcionamento a atuação de distintos grupos de pessoas, sendo eles empregadores, sócios, administradores, prestadores de serviços, fornecedores, empregados, clientes, etc. Almeja-se tutelar todos que lidam com a empresa. Há, nesse sentido, a função social da empresa. ${ }^{5}$ A função social da empresa envolve o papel da atividade econômica em prol da comunidade, independentemente do tipo societário ${ }^{6}$ adotado ou grau de capacidade econômica do agente. ${ }^{7}$ A função social da empresa constitui o poder-dever de o empresário e os administradores da empresa harmonizarem as atividades da empresa, segundo o interesse da sociedade, mediante a obediência de determinados deveres, positivos e negativos (TOMASEVICIUS FILHO, 2003, p. 40). Busca-se com a função social da empresa respeitar, de forma sustentável, a maximização de interesses, riquezas e bem estar individuais e coletivos daqueles que com ela se relacionam, conciliando-se os interesses da sociedade em geral com os interesses daquele que exerce a empresa ${ }^{8}$

Deste modo, mostra-se mais socialmente interessante e útil, sobretudo para a coletividade, que a atividade econômica seja preservada, mesmo na hipótese de sua crise. De fato, se a LREF inseriu um novo espírito ao procedimento falimentar, que busca lançar mecanismo jurídico para regulamentar a crise empresarial, sem dissociar-se do objetivo nacional de promover o desenvolvimento econômico, então é este o ponto de partida para interpretações legislativas. Destaca-se, ainda, que a insolvência é um risco inerente ao exercício da economia de mercado, sendo um ônus a ser suportado por todo aquele que participa da atividade econômica, seja devedor insolvente ou o credor (SONAGLI; GONÇALVES, 2014). Partindo do princípio de que o direito deve acompanhar a evolução do seu povo, espelhando-se em seu comportamento social e econômico, e

5 Emprestar ao Direito uma função social significa, portanto, considerar que os interesses da sociedade se sobrepõem aos interesses do indivíduo, sem que isso implique, necessariamente, a anulação da pessoa humana, justificando-se a ação do Estado pela necessidade de se acabar com as injustiças sociais. Função social significa não-individual, sendo critério de valoração de situações jurídicas conexas ao desenvolvimento das atividades de ordem econômica (AMARAL NETO, 2003, p. 367).

6 A lei n. ${ }^{\circ}$ 6.404/76, que disciplina as Sociedades Anônimas, faz referências à função social da empresa, tal como se lê no art. 116: "Entende-se por acionista controlador a pessoa, natural ou jurídica, ou o grupo de pessoas vinculadas por acordo de voto, ou sob controle comum, que: [...] Parágrafo único. O acionista controlador deve usar o poder com o fim de fazer a companhia realizar o seu objeto e cumprir sua função social, e tem deveres e responsabilidades para com os demais acionistas da empresa, os que nela trabalham e para com a comunidade em que atua, cujos direitos e interesses deve lealmente respeitar e atender” (BRASIL, 1976).

7 Embora voltados os estudos sobre a função social da empresa para a macroempresa, não se pode negar, como parece intuitivo, que as médias e pequenas empresas não deixam também de formar um núcleo de interesses [...] o qual, embora em menor escala, está relacionado com uma indesmentível função social. (LUCENA, 1996, p. 734-735).

8 A empresa é vista como instituição cuja importância transcende a esfera econômica e passa a abarcar interesses sociais dos mais relevantes, como a própria sobrevivência e o bem estar dos trabalhadores que para ela prestam seus serviços e dos demais cidadãos que dividem com ela o mesmo espaço social. (LOPES, 2006, p. 119). 
ressaltando-se a significativa transformação na economia brasileira no que se refere ao abrupto aumento da competitividade e complexidade do mercado, comparada à tímida economia de outros tempos, percebe-se claramente que as chances de fracassar economicamente nunca estiveram tão grandes, tornando vaga e ineficiente uma lei que outrora cumpriu o seu papel e diagnosticando a veemente necessidade dessa lei se readaptar e redefinir nesse sentido (BANDO, 2014).

\section{EM PROL DE AVANÇOS E APERFEIÇOAMENTOS DA LEI DE RECUPERAÇÃO DE EMPRESAS E FALÊNCIA: UMA ABORDA- GEM REFLEXIVA E CONSTRUTIVA.}

Após cerca de 10 anos desde a entrada em vigência da Lei 11.101/05, academicamente, já é possível se fazer uma análise em relação a sua eficiência e objetivos alcançados. A recuperação é importante instrumento e mecanismo legal, e está presente no dia a dia da sociedade em geral, empresas, empresários e sócios da sociedade empresária, sobretudo no atual contexto de notória crise econômica interna no Brasil. ${ }^{9}$ Vê-se que a lei atribuiu, em tese, à recuperação judicial maior possibilidade negocial e proporcionou reforma ao conceber aos credores a responsabilidade pela aprovação do plano de recuperação judicial, em contrariedade à opção legislativa anterior, em que pouca ingerência detinha os credores em relação ao futuro e destino da atividade em concordata.

Esta nova realidade deu ao procedimento recuperacional uma dinâmica viva e imprevisível. Nenhum legislador poderia minimamente imaginar o que seria na prática uma assembléia geral de credores, por exemplo, com sua dinâmica de suspensão e as áreas cinzentas de votação. A modulagem do novo instituto acabou sendo feita pelos seus operadores, seja na área jurídica (advogados, juízes, administradores judiciais), seja na área econômica (reestruturadores financeiros) (WAISBERG, 2015, p. 353). No início, a aplicação ocorreu de forma principiológica, utilizando-se os princípios enumerados no artigo $47 \mathrm{da}$ nova lei falimentar. Este posicionamento é salutar dentro de certa medida, pois a busca do fim colimado da lei de preservar a empresa somente pode ser feita por meio de uma flexibilização que possa acompanhar a dinâmica do processo social e negocial que envolve a recuperação judicial. Mas, evidentemente, não

9 Crescimento, inflação, desemprego, renda, vendas, investimento: para onde que se olhe, a economia brasileira está mal. A queda do Produto Interno Bruto (PIB) no ano passado foi a mais alta em 25 anos, e 2016 não deve ser diferente. A volta do crescimento em 2017 já se tornou mais uma esperança do que uma certeza, e há quem já fale em depressão ao invés de recessão. Os últimos números mostram que a inflação deve entrar em trajetória de desaceleração - mas a partir de patamares que atingiram os perigosos dois dígitos anuais. A população sente no bolso, com uma queda do PIB per capita que pode atingir $10 \%$ em 2 anos e com um desemprego que bateu $9 \%$ na última Pesquisa Nacional por Amostra de Domicílios (PNAD) Contínua e 8,2\% na última Pesquisa Mensal de Emprego, divulgada hoje. (CALEIRO, 2016). 
se pode decidir em desfavor da lei sob o argumento da preservação do negócio, pois cada caso tem que ser analisado detidamente.

Talvez em nenhuma outra área do direito como na aplicação desta parte da lei Falimentar, nossa prática tenha se aproximado tanto do case law do direito Anglo Saxão, uma vez que coube à jurisprudência, em especial do Superior Tribunal de Justiça (STJ) a espinhosa missão de tentar estabilizar as posições controversas que surgiram neste misto de flexibilidade interpretativa e necessidade econômico-financeira (WAISBERG, 2015, p. 340). Questões como a fixação da competência para decidir sobre os bens da empresa recuperanda ${ }^{10}$, a sujeição ou não da cessão fiduciária ao plano de recuperação ${ }^{11}$, a necessidade ou não de CND para a concessão da recuperação judicial ${ }^{12}$, a participação em licitações, ${ }^{13}$ a não sucessão dos adquirentes de Unidades Produtivas Isoladas (UPIs), ${ }^{14}$ o cancelamento de inscrição nos cadastros de devedores inadimplentes após a aprovação do plano ${ }^{15}$, a situação dos adiantamentos a contratos de

10 AgRg no CC 125.893/DF, Rel. Ministra NANCY ANDRIGHI, SEGUNDA SEÇÃO, julgado em 13/03/2013, DJe 15/03/2013) ; AgRg no CC 112.516/SP, Rel. Ministra NANCY ANDRIGHI, SEGUNDA SEÇÃO, julgado em 14/11/2012, DJe 20/11/2012). (BRASIL, 2012). Vide também: AgRg no CC 125.697/SP, Rel. Ministro PAULO DE TARSO SANSEVERINO, SEGUNDA SEÇÃO, julgado em 04/02/2013, DJe 15/02/2013 (BRASIL, 2013c); AgRg no CC 130.138/GO, Rel. Ministro RAUL ARAÚJO, SEGUNDA SEÇÃO, julgado em 09/10/2013, DJe 21/11/2013 (BRASIL, 2013d); CC 116.696/DF, Rel. Ministra NANCY ANDRIGHI, SEGUNDA SEÇÃO, julgado em 24/08/2011, DJe 31/08/2011 (BRASIL, 2011); CC 90.075/SP, Rel. Min. Hélio Quaglia Barbosa, DJ de 04.08.08 (BRASIL, 2008); CC 88661/SP, Rel. Min, Fernando Gonçalves, DJ 03.06.08 (BRASIL, 2008b); STJ - CC 79170 / SP - Rel. Ministro CASTRO MEIRA - DJe 19/09/2008 (BRASIL, 2008c); CC 101.552/AL, Rel. Ministro HONILDO AMARAL DE MELLO CASTRO, DESEMBARGADOR CONVOCADO DO TJ/ AP, SEGUNDA SEÇÃO, julgado em 23/09/2009, DJe 01/10/2009 (BRASIL, 2009).

11 REsp 1263500/ES, Rel. Ministra MARIA ISABEL GALLOTTI, QUARTA TURMA, julgado em 05/02/2013, DJe 12/04/2013) (BRASIL, 2013b). Vide também: Rcl 18.538/PA, Rel. Ministro ANTONIO CARLOS FERREIRA, SEGUNDA SEÇÃO, julgado em 24/09/2014, DJe 06/10/2014 (BRASIL, 2014); AgRg nos EDcl na MC 22.761/MS, Rel. Ministro SIDNEI BENETI, TERCEIRA TURMA, julgado em 05/08/2014, DJe 01/09/2014 (BRASIL, 2014b); AgRg no REsp 1181533/MT, Rel. Ministro LUIS FELIPE SALOMÃO, QUARTA TURMA, julgado em 05/12/2013, DJe 10/12/2013 (BRASIL, 2013e).

12 AgRg no REsp 1376488/DF, Rel. Ministro LUIS FELIPE SALOMÃO, QUARTA TURMA, julgado em 26/08/2014, DJe 01/09/2014) (BRASIL, 2014b); REsp 1187404/MT, Rel. Ministro LUIS FELIPE SALOMÃO, CORTE ESPECIAL, julgado em 19/06/2013, DJe 21/08/2013) (BRASIL, 2013f);

13 AgRg na MC 23.499/RS, Rel. Ministro HUMBERTO MARTINS, Rel. p/ Acórdão Ministro MAURO CAMPBELL MARQUES, SEGUNDA TURMA, julgado em 18/12/2014, DJe 19/12/2014) (BRASIL, 2014c). Vide também: REsp 1187404/MT, Rel. Ministro LUIS FELIPE SALOMÃO, CORTE ESPECIAL, julgado em 19/06/2013, DJe 21/08/2013; REsp 1173735/ RN, Rel. Ministro LUIS FELIPE SALOMÃO, QUARTA TURMA, julgado em 22/04/2014, DJe 09/05/2014) (BRASIL, 2014d).

14 STF. ADI 3934. Número Único: 0004253-55.2007.0.01.0000. MIN. RICARDO LEWANDOWSKI. DATA DE PUBLICAÇÃO DJE 31/03/2011 - ATA N 41/2011. DJE nº 61, divulgado em 30/03/2011. (BRASIL, 2011).

15 REsp 1260301/DF, Rel. Ministra NANCY ANDRIGHI, TERCEIRA TURMA, julgado em 
câmbio (ACCs) ${ }^{16}$, o efeito dos planos de recuperação judicial sobre as garantias fidejussórias ${ }^{17}$, a prorrogação do prazo de suspensão das ações previsto no artigo $6^{\circ}$, parágrafo $4^{\circ}$ de Lei $11.101 / 05^{18}$, a possibilidade de análise de conteúdo de plano aprovado pelo Judiciário ${ }^{19}$, entre outros temas, foram alvo de intensa batalha entre devedores e credores nas instâncias inferiores, chegando ao Superior Tribunal de Justiça (STJ) para decisão com alto grau de diversidade de posições jurisprudenciais nos diferentes Estados da Federação e com efeitos que podiam significar a vida ou a morte de uma empresa (WAISBERG, 2015. p. 339-340). Os tribunais, porém, por mais zelosos que sejam, estão restritos à lege lata e podem atuar somente nos campos onde a interpretação é possível.

Cumpre aos operadores do Direito uma missão maior do que somente o embate nos tribunais ou a hermenêutica da lei posta. É nosso dever, também, utilizar toda a experiência adquirida no dia a dia da recuperação judicial, no mundo real da empresa e da economia, em conjunto com todo o estudo das questões legais, para comandar uma profunda releitura do instituto, de formaa aprimorá-lo (WAISBERG, 2015. p. 41). Não se almeja neste trabalho apenas criticar. A recuperação judicial é sim um grande avanço em relação à concordata. É instrumento essencial de manutenção da empresa e do mercado, com esteio nos ditames da Constituição relacionados à economia e ao emprego, podendo ser um remédio imperioso em tempos atuais de crise tal como notoriamente se vivencia no Brasil.

O instituto inserido em nossa legislação com a reforma da lei falimentar vem sendo testado no Judiciário e tem demonstrado ser um importante instrumento legal, econômico e social. Mas já aponta claramente a necessidade de ser reformado. (WAISBERG, 2015, p.339). Evidenciada como está, a modificação da empresa, hoje protagonista da vida econômica em um sistema

14/08/2012, DJe 21/08/2012) (BRASIL, 2012b).

16 AgRg no REsp 1306924/SP, Rel. Ministro PAULO DE TARSO SANSEVERINO, TERCEIRA TURMA, julgado em 12/08/2014, DJe 28/08/2014) (BRASIL, 2014e); Vide também: REsp 1279525/PA, Rel. Ministro RICARDO VILLAS BÔAS CUEVA, TERCEIRA TURMA, julgado em 07/03/2013, DJe 13/03/2013) (BRASIL, 2013g); AgRg no Ag 1197871/SP, Rel. Ministra MARIA ISABEL GALLOTTI, QUARTA TURMA, julgado em 11/12/2012, DJe 19/12/2012) (BRASIL, 2012c).

17 REsp 1333349/SP, Rel. Ministro LUIS FELIPE SALOMÃO, SEGUNDA SEÇÃO, julgado em 26/11/2014, DJe 02/02/2015) (BRASIL, 2015c); REsp 1326888/RS, Rel. Ministro LUIS FELIPE SALOMÃO, QUARTA TURMA, julgado em 08/04/2014, DJe 05/05/2014) (BRASIL, 2014f).

18 AgRg no CC 125.893/DF, Rel. Ministra NANCY ANDRIGHI, SEGUNDA SEÇÃO, julgado em 13/03/2013, DJe 15/03/2013) (BRASIL, 2013h); AgRg no CC 127.629/MT, Rel. Ministro JOÃO OTÁVIO DE NORONHA, SEGUNDA SEÇÃO, julgado em 23/04/2014, DJe 25/04/2014) (BRASIL, 2014g); AgRg no CC 119.337/MG, Rel. Ministro RAUL ARAÚJO, SEGUNDA SEÇÃO, julgado em 08/02/2012, DJe 23/02/2012) (BRASIL, 2012d).

19 Resp 1314209/SP, Rel. Ministra NANCY ANDRIGHI, TERCEIRA TURMA, julgado em 22/05/2012, DJe 01/06/2012) (BRASIL, 2012e). 
de economia com nítida intervenção do Estado, fez surgir a necessidade de uma mudança na legislação concursal em todo o mundo, de modo a tutelar outros interesses envolvidos na crise econômico-financeira da grande empresa. A crise não diz respeito apenas ao empresário ou a um número menor ou maior de credores, mas ao interesse dos dependentes, vistos como interessados, que são os trabalhadores e a própria sociedade como um todo (GUIMARÃES, 2007b, p. 105).

Outra tendência marcante nos movimentos de alteração da legislação concursal é a passagem da concepção de disciplina de relações meramente inter partes (devedor e credor) para uma visão econômica e social. Doravante, os interesses dos credores passam para o segundo plano e pouco importa a pessoa do devedor: o legislador, e com ele o Juiz, têm principalmente por objetivo a salvaguarda da empresa, em função do valor e do interesse que ela representa para a economia regional ou nacional (GUIMARÃES, 2007b, p. 106). O interesse particular dos credores é hoje confrontado com exigências diferentes, senão contraditórias, que impõem a procura de um novo equilíbrio. Qualquer que seja a imprecisão da noção de empresa, o legislador e a prática estão doravante preocupados em evitar as importantes conseqüências de ordem social e econômica, ou política, que resultam do desaparecimento de um patrimônio produtivo (GUIMARÃES, 2007b, p. 108). Em conseqüência de haver se deslocado do plano jurídico para o econômico a solução da crise da empresa, exige-se um maior empenho do Estado, seja esfera administrativa, seja conjugando os esforços da administração com os esforços do Judiciário (GUIMARÃES, 2007b, p. 108). Observa-se segundo o professor espanhol Gerardo Santini, um maior interesse do Estado pela eliminação ou redução da insolvência da empresa, uma vez que ela não se limita mais, também, em razão de suas dimensões, a arriscar o capital apenas dos sócios, mas também dos poupadores ou outras entidades que se ocupam da intermediação do crédito. O interesse público passa a ser primário em todos os sentidos. (GUIMARÃES, 2007b, p. 108.)

Esses não podem se realizar senão no seio de uma sociedade para com a qual o homem tem deveres e obrigações e no quadro de uma economia a qual ele deve fornecer uma participação efetiva e ativa, extrapolando, portanto, a visão da sociedade empresarial do mero relacionamento entre seus membros (GUIMARÃES, 2007b, p. 109). As críticas e reflexões contidas neste trabalho não devem ser interpretadas como uma negação ao enorme avanço trazido pela LRE, que permitiu salvar inúmeras empresas que estariam fadadas a falência, caso vigente a legislação anterior. Houve uma efetiva e inegável modernização do sistema falimentar brasileiro. Entretanto, o momento requer mudanças urgentes, e o que se propõe é um olhar adiante com o objetivo de aprimorar nosso sistema (PAIVA, 2016). Não reformar, de forma tempestiva, o processo de 
falência, não restaurar adequadamente a concordata, ou mesmo simplesmente substituí-la como, afinal, deu-se, foram equívocos que muito custaram aos agentes e a economia como um todo (LOBATO, 2016). Desse modo, a ideologia normativa subjacente ao Direito Falimentar moderno não se confunde, nem se identifica com as tais fórmulas mirabolantes, dotadas de limitadíssima eficácia com o passar de algum tempo, incapazes de projetar efeitos benéficos e duradouros para impor, ao contrário, desdobramentos nefastos de projeções sombrias (LOBATO, 2016). Aperfeiçoar o processo de falência, modernizando-o naquilo que fosse essencial, incorporando o benefício da experiência haurida em praticamente sessenta anos de vigência do Decreto Lei 7.661/45 tornou-se imperativo à nova ordem normativa que se seguiu (LOBATO, 2016).

Nada do que se expôs até aqui revela aspecto inédito ou desconhecido de tantos quantos militem ou se interessem pela matéria. $\mathrm{O}$ futuro, nesse campo, não aponta soluções criativas ou pouco ortodoxas. Ao contrário, requer debate incessante, reflexões maduras e destituídas de visão fossilizada, insensível a um mundo tão impermanente quanto o de hoje. O esforço, no sentido da reflexão e do aprofundamento, há de ser sempre renovado com o propósito firme de aperfeiçoamento dos institutos aqui considerados (LOBATO, 2016). Entende-se neste trabalho que após passados mais de 10 anos desde a entrada em vigor da 11.101/05, esta vem a merecer nova reflexão. Direito. ${ }^{20}$ Os dados empíricos e quantitativos, de credibilidade, evidenciam a necessidade de aperfeiçoamento da lei 11.101/05. De fato, identifica-se que o percentual de atividades que pleiteam judicialmente a recuperação, que obtenham sucesso, e se reestabelecem no mercado, é extremamento baixo e inadequado. De acordo com o Instituto Nacional de Recuperação de Empresas (INRE) ${ }^{21}$, apenas $5 \%$ dos pedidos de recuperação judicial, feitos no Brasil, tiveram êxito e permitiram a efetiva recuperação da atividade. Assim, entende-se que o tema é de suma importância e merece ser verdadeiramente considerado.

20 Sobre a tendência de nova reflexão da lei 11.101/05, ver em (COSTA, 2016; GUIMARÃES, 2016; LOBATO, 2016; MULLER, 2016; PAIVA, 2016).

21 O Instituto Nacional de Recuperação Empresarial (INRE), entidade sem fins lucrativos criada por juristas, economistas, administradores e engenheiros para manter os meios empresariais e jurídicos atualizados com a nova Legislação e os atos do Estado, visando o monitoramento dos setores de serviço, indústria, comércio e agronegócios em sintonia com notícias do meio ambiente, legislação (visão legal) e economia, para evitar crises financeiras nas empresas e reduzir o número de falências e, ao mesmo tempo, agilizar os processos de recuperação empresarial, com a revisão de falhas e lacunas do atual modelo legislativo. O papel do INRE reveste-se da maior importância, através de suas ações de informar e orientar a classe empresarial, os meios jurídicos e gestores sobre os instrumentos judiciais existentes para que as companhias em dificuldades não entrem em situação falimentar. São membros do conselho e diretoria: Carlos Henrique Abrão; Eronides Aparecido Rodrigues dos Santos; Gustavo Abrão Iunes; Ives Gandra da Silva Martins; Jairo Saddi Roberto Rodrigues; José Eduardo Bélix; Keyler Carvalho Rocha; Marcos Abrão; Rui Schneider. 


\section{A PROBLEMÁTICA IMPERIOSIDADE DE MINORAÇÃO DAS INFORMAÇÕES INCOMPLETAS OU ASSIMÉTRICAS.}

O resultado da negociação se revelará ineficiente caso um dos interessados não esteja devidamente informado quanto ao valor do ativo e se não existir credibilidade quanto a esta informação. As leis recuperacionais tem que criar procedimentos pelos quais se esclareça quais bens se submetem ao processo e quais seriam os valores a serem pagos. O trabalho de auditoria demanda alto custo financeiro. Logo, as leis deveriam, na medida do possível, reduzir as despesas com tal análise. Nesse sentido:

Um obstáculo importante à negociação é a assimetria e incompletude de formação. Obviamente, se uma das partes é desinformada sobre o verdadeiro valor dos ativos e o conteúdo informado não pode, com credibilidade transmitir esta informação, o resultado pode ser ineficiente. Pode até não permitir ser claro para as partes exatamente quais reivindicações são excelentes sobre a empresa (BUTTWILL; WIHLBORG, 2004. p. 11, tradução nossa).22

Verifica-se que não há na Lei 11.101/05 regras próprias para verificação do verdadeiro grau e estado de atividades negociais de quem está em crise, tampouco se impõe a necessidade de elaboração de um relatório circunstanciado feito pelo administrador judicial, ou qualquer outro documento idôneo, sem favorecimentos ou parcialidades, que disponibilizasse a todos os credores as informações indispensáveis às deliberações relacionadas ao destino do devedor. Ademais, não há menção explícita na lei quanto à necessidade de se relacionar quais são os créditos não submetidos à recuperação e nem mesmo se exige a juntada de certidões de débitos perante as Fazendas Públicas. Não existem tais

22 One important impediment to bargaining is asymmetric and incomplete information.12 Obviously, if one of the parties is uninformed about true value of the assets and the informed party cannot credibly convey this information, the outcome may be inefficient. It may not even be clear to the parties exactly what claims are outstanding on the firm. 
exigências nos artigos $51^{23}$ e $53^{24}$ da referida lei.

Tal omissão permite a pertinência, construtiva, da idéia de que a lei 11.101/05 impõe que os credores acabem por ter que decidir sem que tenham conhecimento pleno do montante disponível relativo ao ativo existente para que seja feito o pagamento dos credores, sejam eles concursais ou não.

Nota-se que a exigência de apresentação da viabilidade econômica e do laudo econômico e financeiro, juntamente com a avaliação dos bens e ativos do devedor, assinado por pessoa jurídica ou física especializada, contribui apenas para aumentar os custos financeiros do procedimento e, permite, ainda, não ser dada satisfatória credibilidade, tendo em vista tratar-se de documento unilateral. No mesmo sentido, acaba também por incutir ao credor, que pretenda fundamentar sua eventual objeção ao plano de recuperação, ter de elaborar, por conta própria, análise e auditoria quanto aos documentos apresentados,

23 Art. 51. A petição inicial de recuperação judicial será instruída com:I - a exposição das causas concretas da situação patrimonial do devedor e das razões da crise econômico-financeira;II - as demonstrações contábeis relativas aos 3 (três) últimos exercícios sociais e as levantadas especialmente para instruir o pedido, confeccionadas com estrita observância da legislação societária aplicável e compostas obrigatoriamente de:a) balanço patrimonial;b) demonstração de resultados acumulados; c) demonstração do resultado desde o último exercício social;d) relatório gerencial de fluxo de caixa e de sua projeção;III - a relação nominal completa dos credores, inclusive aqueles por obrigação de fazer ou de dar, com a indicação do endereço de cada um, a natureza, a classificação e o valor atualizado do crédito, discriminando sua origem, o regime dos respectivos vencimentos e a indicação dos registros contábeis de cada transação pendente; IV - a relação integral dos empregados, em que constem as respectivas funções, salários, indenizações e outras parcelas a que têm direito, com o correspondente mês de competência, e a discriminação dos valores pendentes de pagamento; $\mathrm{V}$ - certidão de regularidade do devedor no Registro Público de Empresas, o ato constitutivo atualizado e as atas de nomeação dos atuais administradores;VI - a relação dos bens particulares dos sócios controladores e dos administradores do devedor;VII - os extratos atualizados das contas bancárias do devedor e de suas eventuais aplicações financeiras de qualquer modalidade, inclusive em fundos de investimento ou em bolsas de valores, emitidos pelas respectivas instituições financeiras; VIII - certidões dos cartórios de protestos situados na comarca do domicílio ou sede do devedor e naquelas onde possui filial;IX - a relação, subscrita pelo devedor, de todas as ações judiciais em que este figure como parte, inclusive as de natureza trabalhista, com a estimativa dos respectivos valores demandados. $\$ 1$ o Os documentos de escrituração contábil e demais relatórios auxiliares, na forma e no suporte previstos em lei, permanecerão à disposição do juízo, do administrador judicial e, mediante autorização judicial, de qualquer interessado. $\int 20$ Com relação à exigência prevista no inciso II do caput deste artigo, as microempresas e empresas de pequeno porte poderão apresentar livros e escrituração contábil simplificados nos termos da legislação específica.

\30 O juiz poderá determinar o depósito em cartório dos documentos a que se referem os $\mathbb{S} \mathbb{S}$ 1o e 2odeste artigo ou de cópia destes. (BRASIL, 2005).

24 Art. 53. O plano de recuperação será apresentado pelo devedor em juízo no prazo improrrogável de 60 (sessenta) dias da publicação da decisão que deferir o processamento da recuperação judicial, sob pena de convolação em falência, e deverá conter: I - discriminação pormenorizada dos meios de recuperação a ser empregados, conforme o art. 50 desta Lei, e seu resumo; II demonstração de sua viabilidade econômica; e III - laudo econômico-financeiro e de avaliação dos bens e ativos do devedor, subscrito por profissional legalmente habilitado ou empresa especializada. Parágrafo único. O juiz ordenará a publicação de edital contendo aviso aos credores sobre o recebimento do plano de recuperação e fixando o prazo para a manifestação de eventuais objeções, observado o art. 55 desta Lei.(BRASIL, 2005). 
transformando-se em mais custos, os quais serão somados ao crédito existente que não foi recebido ainda.

O teste da viabilidade econômica para fins de deferimento do processamento da recuperação judicial não se encontra positivado a Lei 11.101/05. Pelo contrário, o art. 52 da LRF estabelece que "estando em termos a documentação exigida no artigo 51 desta lei, o juiz deferirá o processamento da recuperação judicial”. Conforme a jurisprudência consolidada nos Tribunais, este comando normativo impõe, para o deferimento do processamento da recuperação, que se realize mera análise formal, não material, dos documentos indicados no artigo 51 da LRF. Assim, por exemplo, basta que se encontrem presentes documentos intitulados "balanços", que possuam conteúdo de balanço, sem que se exija a análise do conteúdo desses documentos. Noutras palavras, não há que auditarem-se os balanços por ocasião do deferimento do processamento da recuperação judicial (CAVALLI, 2016, p. 126).

Em Portugal, no regime do CPEREF, que foi instituído pelo Decreto Lei 132/93, de 23 de abril, o qual atualmente encontra-se revogado pelo Decreto Lei 53/2004, que se refere ao atual Código de Insolvência, tratava-se acerca da verificação pelo gestor judicial quanto aos documentos apresentados pelo devedor.(DUARTE, 2004). De acordo com aquele texto normativo, qualquer interessado em saber o valor da empresa é destinado para a documentação apresentada pelo próprio requerente e que foi informada na petição inicial. Via leitura do balanço e correspondente análise do mapa de reintegrações e amortizações anexo, conhece-se o ativo da recuperanda e o respectivo valor (DUARTE, 2004).

Porém, é necessário afirmar o juízo de onde partirá tais documentos, pois além de poderem ser incorretos, seriam nitidamente insuficientes para saber-se o valor da empresa. Tal imperfeição e insuficiência pode até mesmo decorrer de dados desatualizados ou contabilização de acordo com as necessidades e vicissitudes do devedor. Salvo poucas exceções, a análise será equivocada, por basear-se em dados com pouca credibilidade. (DUARTE, 2004). Fazer fé nos próprios documentos da recuperanda, virgens de qualquer inspeção ou análise, representará sobretudo risco ou ingenuidade, que são contrárias à idéia de informação objetiva e segura. (DUARTE, 2004, p. 87).

A desconfiança dos credores em relação ao pedido inicial, na Lei 11.101/05, decorre da não adoção da unicidade procedimental, além de permitir que a legislação autorize que o pedido de recuperação venha sem estar acompanhado de imediato do plano de recuperação, o qual somente será conhecido dentro de 60 dias. Aos credores permite-se, nos termos do artigo 55 25 , em até 30 dias seguintes, oporem objeções ao plano, mesmo com os poucos

25 Art. 55. Qualquer credor poderá manifestar ao juiz sua objeção ao plano de recuperação judicial no prazo de 30 (trinta) dias contado da publicação da relação de credores de que trata o $\mathbb{S} 20$ do art. 7o desta Lei. Parágrafo único. Caso, na data da publicação da relação de que trata o caput deste artigo, não tenha sido publicado o aviso previsto no art. 53, parágrafo 
elementos que dispõem. O sistema brasileiro, diante da ausência da adequada informação, proporciona desincentivos para a participação dos credores durante a oportunidade, única, em que a lei lhes concede oportunidade para sugerir alterações no plano.

Uma análise econômica pressupõe a apreensão das opções entre diferentes condutas bem como dos custos, riscos e benefícios envolvidos em cada uma destas escolhas. A compreensão do número de opções de conduta disponíveis aos agentes econômicos e dos incentivos que encontram em cada uma delas para a maximização de seus interesses (medidos pela relação entre seus custos e seus benefícios) somente se revela digna de credibilidade se efetuada por meio de avalições numericamente mensuráveis. Ao atentar para a relação quantitativa entre diferentes variáveis a Economia, em decorrência, trata seu objeto de estudo a partir de noções como custos, riscos e ganhos (modalidades de incentivos), todas suscetíveis de serem expressas por meio de gráficos e equações que espelham a relação entre elas. Estudar o Direito sob uma perspectiva econômica exige que a legislação seja analisada à luz dos custos que acarreta para os agentes, dos benefícios que traz para cada um deles e também do número de opções que podem ser legalmente oferecidas a estes sujeitos. Tal estudo só se valida se amparado por análises eminentemente quantitativas marcadas pela precisão matemática (PIMENTA, 2006a, p. 16, grifo do autor).

A idéia de que indivíduos possam agir como maximizadores racionais de suas preferências (sejam elas quais forem), e que dão ensejo a padrões interativos relativamente estáveis (as situações de equilíbrio), sugere que os indivíduos possam também responder a incentivos (SALAMA, 2008, p. 22).

Princípio 4: As Pessoas Reagem a Incentivos: Como as pessoas tomam decisões por meio da comparação de custos e benefícios, seu comportamento pode mudar quando os custos ou benefícios mudam. Em outras palavras, as pessoas reagem a incentivos. [...] Os formuladores de políticas públicas nunca devem esquecer-se dos incentivos, já que muitas políticas alteram os custos e benefícios para as pessoas e, portanto, alteram seu comportamento. (MANKIW, 2009a,p. 7)

Os credores, mesmo querendo participar, não têm todas as informações necessárias para elaborar um plano alternativo. Aliás, mesmo para avaliar a consistência do plano apresentado pelo devedor, carecem e informações plenas (COELHO, 2005, p. 162). No mesmo sentido, os credores acabam por não ficarem interessados em arcar com os custos para elaboração de planos alternativos, já que isso aumentaria, ainda mais, o seu prejuízo, na hipótese de falência do devedor (COELHO, 2005).

O sistema brasileiro ao utilizar a dicotomia procedimental, deixa de obrigar ao administrador a apresentação de qualquer documento que ateste a consistência, plausibilidade, veracidade e idoneidade dos dados que

único, desta Lei, contar-se-á da publicação deste o prazo para as objeções. 
foram disponibilizados pelo devedor anteriormente à data de realização da assembleia geral. No Brasil, somente quando declarada a falência é que deverá o administrador inserir relatório sobre as causas e circunstâncias que conduziram à situação de falência. ${ }^{26}$ Tal providência se revela tardia para que se possa efetivamente orientar os credores e auxiliar a tarefa judicial de manter e preservar a empresa. Nos ordenamentos jurídicos pesquisados neste trabalho, percebe-se que a exigência de tal relatório do administrador judicial é, em regra, feita. E é a partir dele que se vota em deliberação sobre a eventual continuação das atividades do devedor. O ordenamento Alemão impõe que este relatório tenha como objetivo "esclarecer se existem perspectivas de manter em todo ou em parte a empresa do devedor, as possibilidades existentes para um plano de insolvência e as consequências resultantes deste para cada credor em relação à satisfação de seus créditos” (InsO $\mathbb{S} 156$, BERGER, 2001, p. 292). Assim, com esteio nestas informações a Assembléia de Credores decide "se a empresa será desativada ou se continuará provisoriamente a funcionar", inclusive mediante a possibilidade de que ao administrador seja atribuída a incumbência de elaborar um plano de insolvência e projetar os objetivos perseguidos através do mesmo (InsO $\$ 156$, BERGER, 2001, p. 292).

$\mathrm{Na}$ Argentina, a legislação prevê a elaboração do "informe geral del síndico" no prazo de trinta dias após a elaboração do "informe individual dos créditos". Em tal relatório são determinadas matérias que servirão ao Juiz quando da fundamentação, de suas futuras decisões e principalmente aos credores no momento da deliberação de aprovar o acordo preventivo ou permitir a quebra. Diante disso, exige-se que seja o mais completo e específico possível, sobretudo para permitir adequado conhecimento ao credor que votará, logo depois, a aprovação ou não da proposta (FASSI; GEBHARDT, 2005). A Espanha, pela Ley n. 22/2003, impõe aos administradores concursais a obrigação de elaborar o relatório prescrito no artigo 75 , em que deve constar ${ }^{27}$ :

Artigo 75. Estrutura do relatório [...] $1^{\circ}$ - A análise dos fatos e circunstâncias do devedor expressa no relatório que o inciso $2^{\circ}$, parágrafo $2^{\circ}$, do artigo $6^{\circ}$.

26 Art. 22. Ao administrador judicial compete, sob a fiscalização do juiz e do Comitê, além de outros deveres que esta Lei lhe impõe: [...] III - na falência:[...]e) apresentar, no prazo de 40 (quarenta) dias, contado da assinatura do termo de compromisso, prorrogável por igual período, relatório sobre as causas e circunstâncias que conduziram à situação de falência, no qual apontará a responsabilidade civil e penal dos envolvidos, observado o disposto no art. 186 desta Lei.(BRASIL, 2005).

27 Artículo 75. Estructura del informe. 1. El informe de la administración concursal contendrá: 1. ${ }^{\circ}$ Análisis de los datos y circunstancias del deudor expresados en la memoria a que se refiere el número $2 .^{\circ}$ del apartado 2 del artículo $6.2 .^{\circ}$ Estado de la contabilidad del deudor y, en su caso, juicio sobre las cuentas, estados financieros, informes y memoria a que se refiere el apartado 3 del artículo 6. Si el deudor no hubiese presentado las cuentas anuales correspondientes al ejercicio anterior a la declaración de concurso, serán formuladas por la administración concursal, con los datos que pueda obtener de los libros y documentos del deudor, de la información que éste le facilite y de cuanta otra obtenga en un plazo no superior a quince días. 
$2^{\circ}$ - Estado da contabilidade devedor e, neste caso, avaliação sobre as contas, estados financeiros, exposição e memória que se refere o parágrafo $3^{\circ}$ do artigo $6^{\circ}$. Se o devedor não apresentou as constas anuais correspondentes ao exercício anterior à declaração do concurso, estas serão apresentadas pela administração concursal, com os dados obtidos a partir dos livros e documentos do devedor, de informação que este disponibilize e da que se obtenha em prazo não superior a quinze dias. (ESPANHA, 2003, tradução nossa).

3 - Relato das principais decisões e atividades da administração concursal. (2) - Ao relatório serão juntados os seguintes documentos: 1 . Inventário da massa ativa. 2 - Lista de credores. 3. Se o caso, a avaliação das propostas de convênio que foram apresentadas. (3) Concluirá o relatório a exposição motivada dos administradores concursais acerca da situação patrimonial do devedor e de dados e circunstâncias que possam ser relevantes para a ulterior tramitação do concurso. (ESPANHA, 2003, tradução nossa) ${ }^{28}$

Nos Estados Unidos, o dever de informação paira sobre o dever que permita aos credores ter a "adequada informação", ou seja, detalhada de forma suficiente. Significa a informação mais ampla e detalhada possível acerca da natureza do negócio e história do devedor, bem como situação de seus livros e registros empresariais, de modo que se permita a qualquer credor formar juízo seguro sobre o plano proposto, sem, contudo, ser necessário indicar outras possibilidades ou propostas da recuperação. ${ }^{29}$ Nos Estados Unidos tal função cumpre aos comitês, que tem de participar da elaboração do plano, bem como sugerir e aconselhar aos membros em relação aos planos formulados. ${ }^{30}$ Por outro lado, no Brasil não há designação para esta atribuição a indivíduos ou a órgãos colegiados. Na França, atribui-se ao administrador, mediante concurso

$283 .^{\circ}$ Memoria de las principales decisiones y actuaciones de la administración concursal. 2. $\mathrm{Al}$ informe se unirán los documentos siguientes: 1 . $^{\circ}$ Inventario de la masa activa. $2{ }^{\circ}$ Lista de acreedores. $3 .^{\circ}$ En su caso, el escrito de evaluación de las propuestas de convenio. $4 .^{\circ}$ En su caso, el plan de liquidación. 5..$^{\circ}$ Valoración de la empresa en su conjunto y de las unidades productivas que la integran bajo la hipótesis de continuidad de las operaciones y liquidación. 3. El informe concluirá con la exposición motivada de los administradores concursales acerca de la situación patrimonial del deudor y de cuantos datos y circunstancias pudieran ser relevantes para la ulterior tramitación del concurso.

29 Code $\mathbb{S} 1125$ - Post petition disclosure and solicitation. (1) “adequate information" means information of a kind, and in sufficient detail, as far as is reasonably practicable in light of the nature and history of the debtor and the condition of the debtor's books and records, including a discussion of the potential material Federal tax consequences of the plan to the debtor, any success or to the debtor, and a hypothetical invest or typical of the holders of claims or interests in the case, that would enable such a hypothetical investor of the relevant class to make an informed judgment about the plan, but adequate information need not include such information about any other possible or proposed plan. Vide: 11 U.S. Code $\mathbb{S} 1125$ - Post petition disclosure and solicitation.

30 Ver:11 U.S. Code Subchapter I - Officers and administrativo. Code \$ 1103 - Powers and duties of committees. [...] (c) A committe appointed under section 1102 of this titlemay. [... (3) participate in the formulation of a plan, advisethoserepresentedbysuchcommitteeofsuchcommittee'sdeterminations as to any plan formulated, and collectand file with the court accept ancestor rejections of a plan. 
do devedor e auxílio de eventuais um ou mais peritos, a incumbência de ser feito um relatório de balanço econômico e social da atividade que inclua a natureza e relevância das dificuldades econômicas. Caso a atividade explore instalações prescritas no Código de Meio Ambiente, terá que acrescer ao seu relatório balanço ambiental e, diante deste relatório, o administrador poderá propor o plano de sauvegarde. ${ }^{31}$ Em Portugal, o artigo 155 do CIRE impõe ao administrador da insolvência que elabore um criterioso relatório ${ }^{32}$ indicando:

1 - $\mathrm{O}$ administrador da insolvência elabora um relatório contendo:

a) A análise dos elementos incluídos no documento referido na alínea c) do n. ${ }^{\circ} 1$ do artigo $24^{\circ}$;

b) A análise do estado da contabilidade do devedor e a sua opinião sobre os documentos de prestação de contas e de informação financeira junto aos autos pelo devedor;

c) A indicação das perspectivas de manutenção da empresa do devedor, no todo ou em parte, da conveniência de se aprovar um plano de insolvência, e das consequiências decorrentes para os credores nos diversos cenários figuráveis; d) Sempre que se lhe afigure conveniente a aprovação de um plano de insolvência, a remuneração que se propõe auferir pela elaboração do mesmo;e) Todos os elementos que no seu entender possam ser importantes para a tramitação ulterior do processo. 2 - Ao relatório são anexados o inventário e a lista provisória de credores. 3 - O relatório e seus anexos deverão ser juntos aos autos pelo menos oito dias antes da data da assembleia de apreciação do relatório.

Ainda em relação a Portugal, vê-se que a finalidade de tal relatório, elaborado pelo administrador da insolvência, é possibilitar que a assembléia delibere sobre assuntos posteriores do processo e, por isso, deve evidenciar as diferentes opções existentes, bem como as conseqüências previsíveis de a assembléia decidir em quaisquer dos sentidos (LEITÃO, 2005).

Verifica-se que a Lei 11.101/05, no Brasil, não promove incentivos positivos para o fornecimento da adequada e simétrica informação aos credores, os quais, caso tenham intenção de analisar de forma mais profunda o contexto e perfil da crise econômica e financeira do devedor, bem como viabilidade de seu plano de recuperação, terão que arcar com elevados custos financeiros, individualmente. A legislação brasileira possibilita ao devedor a escolha entre

31 Chapitre III : De l'élaboration du bilan économique, social et environnemental.Article L6231. L'administrateur, avec le concours du débiteur et l'assistance éventuelle d'un ou plusieurs experts, est chargé de dresser dans un rapport le bilan économique et social de l'entreprise. Le bilan économique et social précise l'origine, l'importance et la nature des difficultés de l'entreprise. Dans le cas où l'entreprise exploite une ou des installations classées au sens du titre Ier du livre $\mathrm{V}$ du code de l'environnement, le bilan économique et social est complété par un bilan environnemental que l'administrateur fait réaliser dans des conditions prévues par décret en Conseil d' Etat.

32 Exemplo real deste relatório pode ser visto em: (BRAGA, 2014). http://n-insolvencias.com/ sites/ninsolvencias/files/insolvencias_1414159866/2494_Relatorio_Art155.pdf 
prosseguir com sua atividade de natureza empresária, ao lhe permitir viabilizar a superação da situação de crise econômica financeira ${ }^{33}$, ou, por outro lado, requerer ao juízo a autofalência, expondo as razões da impossibilidade de se prosseguir com a atividade empresarial. ${ }^{34}$ o entanto, os motivos pelos quais o devedor considera estarem presentes para realizar o pleito de recuperação judicial, não são, de forma suficiente e adequada, de conhecimento dos credores, no momento de elaboração da petição inicial. Tal fato acaba por fazer com que os credores deliberem sem terem todas as informações adequadas, o que permite a preservação da empresa que não seja viável e extinguindo-se as viáveis.

Assim, nestes casos, não se produzem resultados eficientes, pois não se atende aos critérios da lei, sobretudo quanto à manutenção da empresa viável e também do interesse dos credores. Contribui-se até mesmo para que no mercado de crédito crie-se insegurança, capaz de aumentar os custos de negociações futuras junto aos financiadores, investidores e fornecedores. Não se nota na Lei 11.101/05 um mecanismo que contribua para facilitar a distinção, antes da deliberação da assembléia geral de credores, entre as atividades viáveis e as inviáveis.

Michelle J. White expõe a expressão filtering failure, que significa a existência de erro quando da avaliação dos devedores em crise, o que enseja a possibilidade de que atividades economicamente eficientes fossem liquidadas. Este seria o error type 1. Por outro lado, seria o error type 2 permitir as atividades que são economicamente ineficientes, a sua reorganização. ${ }^{35}$ Assim, é possível que o empresário devedor assuma unilateralmente ser viável economicamente, mas, porém sem sê-lo, ao passo que os credores não terão dados para concordar ou discordar de tal afirmação do devedor. Isso configura o error type 2.

33 Art. 47. A recuperação judicial tem por objetivo viabilizar a superação da situação de crise econômico-financeira do devedor, a fim de permitir a manutenção da fonte produtora, do emprego dos trabalhadores e dos interesses dos credores, promovendo, assim, a preservação da empresa, sua função social e o estímulo à atividade econômica.(BRASIL, 2005).

34 Art. 105. O devedor em crise econômico-financeira que julgue não atender aos requisitos para pleitear sua recuperação judicial deverá requerer ao juízo sua falência, expondo as razões da impossibilidade de prosseguimento da atividade empresarial, acompanhadas dos seguintes documentos. (BRASIL, 2005).

35 3.1.2. Models with asymmetric or incomplete information Turn now to "filtering failure." Suppose there are two types of financially distressed firms: type 1 firms that are economically efficient and should reorganize versus type 2 firms that are economically inefficient and should liquidate. In the first-best bankruptcy outcome, all type 1 firms would reorganize and all type 2 firms would liquidate. "Filtering failure" occurs in bankruptcy whenever type 1 firms liquidate and/or type 2 firms reorganize. White (1994) examined an asymmetric information model of filtering failure under which managers of failing firms are assumed to know their firms' type, but creditors do not. The structure of the model incorporates features of U.S. bankruptcy law, including managers' right to choose between Chapter 7 versus Chapter 11, managers' right to offer the first reorganization plan under Chapter 11, and creditors' right to accept or reject managers' proposed plan. But the model ignores conflicts of interest among creditors. (WHITE, 2007. p. 17). 
Verifica-se, assim, que para se ter conhecimento acerca da opção dos administradores que gerenciam a atividade em crise financeira, econômica e patrimonial, quanto a sê-la eficiente ou não, pressupõe que as informações colocadas à disposição de todos os interessados sejam simétricas e completas. Ou seja, identificar se a escolha do empresário é eficiente ao se optar pela falência ou liquidação, na hipótese em que seus recursos disponíveis levam a essa solução e, da mesma forma, identificar se a opção pela recuperação foi feita tão somente nos casos em que era recomendada e adequada, não permite a assimetria nas informações.

Percebe-se que a Lei 11.101/05 não prevê meio procedimental adequado para completa informação e cognição dos credores, causando assimetria de informações, ao não impor ao administrador judicial o dever de produzir relatório circunstanciado sobre a verdadeira situação do devedor em momento anterior à ocorrência de assembleia de geral de credores, com o objetivo de aceitar, rejeitar ou modificar o plano de recuperação. Para maior eficiência, deveria ser apresentado à assembleia geral de credores documento confeccionado que contivesse um relatório detalhado, feito por pessoa imparcial e totalmente desvinculada da administração e gerência do devedor, que tenha total acesso ao dia a dia da atividade, livros, estabelecimento e qualquer documento. Neste caso, ter-se-ia um quadro mais seguro quanto à real situação do devedor e eventual viabilidade do plano, em termos econômicos. Desta forma haveria mais eficiência, com maior possibilidade de alocação dos recursos escassos, maior probabilidade de alcance dos fins almejados, minimização de custos e ocorrência de mais incentivos positivos à participação e interação dos credores.

Ademais, um outro aspecto chama atenção e diz respeito exatamente à existência de assimetria de informações. Inexiste na atual Lei 11.101/05 qualquer princípio de validação econômica do plano de recuperação. Entendese que a lei brasileira não incluiu de forma suficiente previsão sobre fundamento econômico para aprovação do plano de recuperação, ao não impor a necessidade de realização de pagamento ao menos daquele valor em que os credores eventualmente receberiam em caso de falência e liquidação. A tradicional doutrina de José Xavier Carvalho de Mendonça (1955) anteriormente adotada pela lei falimentar de 1908 já preconizava:

Não se compreende a concordata sem a equivalência dos sacrifícios, que se exigem dos credores, as vantagens de evitar a liquidação judicial na falência. Não seria justo levar o rigor da Lei ao ponto de sacrificar o interesse dos credores em benefício exclusivo do falido, ou credores astutos. A falência não é meio de enriquecer. (MENDONÇA, 1955, p. 384-385).

A legislação de 1908 previa ${ }^{36}$ :

36 Verseu inteiro teor disponível em Câmara Legislativa. 
Art. 108. Os embargos que os credores dissidentes, presentes á assembléa, podem oppôr, deverão ter por fundamento:

1. Inobservancia das formalidades e dos requisitos estabelecidos por Lei para a formação da concordata, a inclusão indevida de credores, cujos votos influiram na acceitação da proposta ou violação das regras prescriptas para a convocação e reunião dos credores.

2. Maior sacrificio aos credores que a liquidação na fallencia, attendendo á proporção entre o valor do activo e a porcentagem offerecida.(BRASIL, 1908, grifo nosso).

Ao se analisar o Bankruptcy Code nota-se que para que ocorra confirmação judicial, dentre outros requisitos, o plano deve oferecer aos credores, ao menos, valor igual ou superior àquele vislumbrado e previsto em caso de liquidação. ${ }^{37}$ Em Portugal, há neste caso a possibilidade de impugnação manifestada pelo credor:

Art. 216. Não homologação a solicitação dos interessados. 1 - O juiz recusa ainda a homologação se tal lhe for solicitado pelo devedor, caso este não seja o proponente e tiver manifestado nos autos a sua oposição,

anteriormente à aprovação do plano de insolvência, ou por algum credor ou sócio, associado ou membro do devedor cuja oposição haja sido comunicada nos mesmos termos, contanto que o requerente demonstre em termos plausíveis, em alternativa, que: a) A sua situação ao abrigo do plano é previsivelmente menos favorável do que a que interviria na ausência de qualquer plano, designadamente face à situação resultante de acordo já celebrado em procedimento extrajudicial de regularização de dívidas; b) $\mathrm{O}$ plano proporciona a algum credor um valor económico superior ao montante nominal dos seus créditos sobre a insolvência, acrescido do valor das eventuais contribuições que ele deva prestar. (PORTUGAL, 2016)

No mesmo sentido, David Smith e Per Stromberg(2003)destacam a importância da validação econômica do plano, de modo a se evitar intrigas entre os próprios credores, diminuindo-se a probabilidade de que planos viáveis sejam rejeitados. ${ }^{38}$ Em relação ao sistema brasileiro, verifica-se sê-lo ineficiente

37 Ver: 11 U.S. Code $\mathbb{S} 1129$ - Confirmation of plan. [...]. With respect to a class of interests - (i) the plan provides that each holder of an interest of such class receive or retain on account of such interest property of a value, as of the effective date of the plan, equal to the greatest of the allowed amount of any fixed liquidation preference to which such holder is entitled, any fixed redemption price to which such holder is entitled, or the value of such interest; or (ii) the holder of any interest that is junior to the interests of such class will not receive or retain under the plan on account of such junior interest any property.

38 Second, voting rules are crucial to implementing reorganization plans when a minority of creditors might strategically oppose a plan. The U.S. Chapter 11 code has a particularly clever system to prevent hold-outs. First, only "impaired" classes - defined to be those claimants that would receive some payoff less than their face value but greater than zero in liquidation - get to vote. Those classes that would receive nothing or be fully paid back in the plan, are precluded from voting, and thus strategically holding out. But creditors have to be offered a plan that at least covers their estimated payoff in case of liquidation. This is important, since it prevents the 
haja vista a ausência de informações claras e por estar presente a assimetria, conforme exposto em item anterior neste trabalho. ${ }^{39}$ Para que haja eficiência, deve haver a avaliação econômica da atividade em juízo, por ser requisito para que ocorra a adequada votação dos credores quando em assembléia geral. Ademais, a avaliação econômica deve se orientar com base em critérios ligados à liquidação e continuidade da atividade ao longo do tempo futuro, via cálculo do aviamento ou goodwill. ${ }^{40} 4142$

backers of the plan from simply overruling some classes of creditors by offering them a zero payout and locking them out from the voting. (SMITH; STRÖMBERG, 2003, p. 19).

39 Viu-se em item anterior que a Lei 11.101/05 não prevê meio procedimental adequado para completa informação e cognição dos credores, sobre a viabilidade econômica da atividade, causando assimetria de informações, ao não impor ao administrador judicial o dever de produzir relatório circunstanciado sobre a verdadeira situação do devedor em momento anterior à ocorrência de assembléia de geral de credores, com o objetivo de aceitar, rejeitar ou modificar o plano de recuperação. Diz-se que a exigência de apresentação da viabilidade econômica e do laudo econômico e financeiro, juntamente com a avaliação dos bens e ativos do devedor, assinado por pessoa jurídica ou física especializada, contribui apenas para aumentar os custos financeiros do procedimento e, permite, ainda, não ser dada satisfatória credibilidade, tendo em vista tratar-se de documento unilateral.

40 Para Henrique Vaz Duarte (2004, p. 97-98) o critério da liquidação “traduz-se no somatório material dos elementos patrimoniais que compõem a empresa que vai cessar a sua actividade. Os bens são tratados e avaliados individualmente, de acordo com o seu custo, o seu estado físico atual, com maior ou menor deterioração, podendo servir como auxiliar de avaliação a comparação com o preço da venda de um bem novo. Não se avalia neste método a empresa vista como unidade econômica e instrumento gerador de riqueza. A liquidação patrimonial, característica paradigmática de uma alienação falimentar, será sinónimo de delapidação patrimonial, já que não se terá como objectivo a exploração futura da empresa, quando muito seu desmantelamento". Já o critério da continuidade, rendimento ou cash-flow respeita à soma actualizada dos resultados da exploração esperados. Este modelo de avaliação tem em linha de conta a empresa como entidade dinâmica, com passado presente e futuro e a sua correlativa aptidão para produzir rendimento, gerar lucro. No fundo, alicerça-se este método numa projecção vindoura de fluxos de tesouraria, numa previsão de receitas e despesas susceptíveis de incorporar no preço/valor final o potencial futuro dos respectivos negócios. Trata-se de um critério de avaliação que, envolvendo uma variedade de componentes (taxa de juros, risco, índices de inflação, nível de crescimento, sinergias, rentabilidade, etc.) permite conhecer, na actualidade, o valor futuro do good will da empresa."

41 O goodwill é tratado em nosso vernáculo como “aviamento”. Sobre a evolução histórica detalhada do aviamento ou goodwill, desde o primeiro registro de sua utilização em 1571 na Inglaterra, considerando-se o primeiro trabalho sistemático possuindo-o como tema central, em 1891, de autoria de Francis More, em publicação de seu artigo na revista The Accountant, abordando a forma de sua avaliação, até a elaboração da tese de doutoramento de Eliseu Martins na USP, a qual foi um marco de referência da literatura brasileira, ver Schmidt (2002, p. 38-42), bem como Fernandes e Schmidt (2005, p. 77-78).

42 Para Celso Barreto Filho "o aviamento é o resultado de um conjunto de variados fatores pessoais, materiais e imateriais, que conferem a dado estabelecimento in concreto a aptidão de produzir lucros". (BARRETO FILHO, 1988, p. 169). Para Eduardo Goulart Pimenta "todo estabelecimento traz consigo, devido as circunstância que o envolvem, um determinado potencial de lucratividade, chamado também de aviamento. Este elemento incorpóreo ligado ao instituto do estabelecimento é, como se pode presumir, extremamente variável, dependendo de inúmeros elementos que vão desde a qualidade dos produtos ofertados e a localização do estabelecimento até o nível de comprometimento e competência dos empregados e administradores do negócio”. (PIMENTA, 2004ap. 116). Nas palavras de Marcelo Marco Bertoldi e Márcia Carla Pereira Ribeiro (2006), sobre o aviamento, "Também conhecido pela expressão goodwill of a trade (do direito anglo-saxão), trata-se o aviamento do sobre valor verificado com a reunião de todos os bens integrantes do estabelecimento empresarial que, 


\section{Nota-se que as variáveis consideradas em todas as fórmulas para tal}

agrupados, têm o propósito de gerar riquezas. Quanto melhor administrados os elementos integrantes do estabelecimento, maior será sua aptidão para a obtenção de lucros. São vários elementos materiais, imateriais e pessoais que conferem ao estabelecimento a capacidade de produzir lucros, sendo que é conforme a específica qualidade de cada um destes elementos que teremos uma capacidade maior ou menor de obtenção de lucros". (BERTOLDI; RIBEIRO, 2006, p. 99). As elementares palavras de José Xavier Carvalho de Mendonça expõem: "sob esse qualificativo queremos designar a aptidão ou disposição do estabelecimento comercial ao fim a que se destina. O aviamento, que se forma com o tempo, com a obra diligente do comerciante, com a bondade dos produtos, com a honestidade, é o índice da prosperidade e da potência do estabelecimento comercial, ao qual se acha visceralmente unido". (MENDONÇA, 1955, p. 21). Nas palavras de Priscila Maria Pereira Corrêa da Fonseca, "É, por via de efeito, uma qualidade ou atributo do estabelecimento relacionado, quer com a respectiva excelência, reputação e eficiência - as quais, via de regra, são creditadas às qualidades pessoais daqueles que o dirigem (aviamento subjetivo ou personal goodwill) -, quer com o ponto onde se encontram localizadas as respectivas instalações (aviamento objetivo ou local goodwill) (FONSECA, 2007, p. 220). Também salienta Haroldo Malheiros Duclerc Verçosa, "A capacidade de geração de lucros, proporcionados pelos estabelecimentos comerciais, é chamada “aviamento". Esse aviamento pode decorrer fundamentalmente da própria localização do estabelecimento (aviamento objetivo, ou local goodwill) ou da especial e competente atuação do empresário à sua frente (aviamento subjetivo, ou personal goodwill) (VERÇOSA, 2004, p. 249).Em trabalho acadêmico específico sobre o assunto, para Eliseu Martins, são fatores que ensejam o goodwill: know-how, propaganda eficiente, localização geográfica, habilidade administrativa fora dos padrões comuns, treinamento eficiente dos empregados, relações públicas favoráveis, legislação favorável e condições monopolísticas (MARTINS, 1972, p. 59). A doutrina especializada contábil também expõe poder ser o aviamento ou goodwill classificado em comercial, industrial, financeiro, político, pessoal, profissional, de marca ou nome comercial, dependendo dos fatores essenciais que o ensejaram. Ao citarem Paton e Paton, Luciane Alves Fernandes e Paulo José Luiz dos Santos Schmidt observam: "Goodwill comercial: decorrente de serviços colaterais, como equipe amável de vencedores; entregas convenientes; facilidade de crédito; espaço físico apropriado para serviços de manutenção; atributo de qualidade do produto em relação ao preço; atitude e hábito do consumidor como fruto de nome comercial e marca tornados proeminentes em função da propaganda persistente; localização da entidade. Goodwill industrial: função de altos salários, baixa rotatividade de empregados, oportunidades internas satisfatórias para acesso às posições hierárquicas superiores, serviços médicos, sistema de segurança adequado, quando esses fatores contribuem para a boa imagem da entidade, e a redução do custo unitário da produção gerado pela força de trabalho que opera nessas condições. Goodwill financeiro: oriundo da atitude dos investidores, fontes de financiamento e de crédito em função de a entidade possuir sólida situação para cumprir suas obrigações e manutenção de sua imagem, ou, ainda, captar recursos financeiros que lhe permitam aquisições de matéria-prima ou mercadorias em melhores termos e preços. Goodwill político: é aquele que surge em decorrência de um bom relacionamento com o Governo" (SCHMIDT; SANTOS, 2002. p. 44-45). Veja-se, nesse sentido, Rubens Famá e Marcelo Monteiro Perez, em dissertação de mestrado específica sobre o assunto, que aduz que o goodwill é considerado sob três perspectivas: como excesso de preço pago na compra de um empreendimento ou patrimônio, em relação ao valor dos seus ativos líquidos, conforme as cotações de mercado; nas consolidações contábeis, como o excesso de valor pago pela sociedade controladora por sua participação nos ativos líquidos de suas subsidiárias; como o valor atual dos lucros futuros esperados, descontados por seu custo de oportunidade (FAMÁ; PEREZ, 2006). Para os contabilistas Eldon Hendriksen e Michael Van Breda "O valor presente de lucros superiores. O enfoque à mensuração de goodwill que é encontrado mais comumente na literatura contábil é o que pressupõe que o goodwill representa o valor presente de lucros futuros esperados (ou pagamento a proprietários) acima daquilo que poderia ser considerado um retorno normal" (HENDRIKSEN; BREDA, 1999, p. 392). Paulo Schmidt e José Luiz dos Santos (1997, p. 392) corroboram nesse sentido, ao afirmarem que: $O$ goodwill, segundo Iudícibus, pode ser analisado sob as seguintes perspectivas: a) excesso de preço pago na compra de um negócio sobre o valor de mercado de seus ativos líquidos; b) nas consolidações, o excesso de valor pago pela investidura por sua participação nos ativos da subsidiária; c) valor atual dos lucros futuros esperados, descontados por seus custos de oportunidade (goodwill subjetivo).” O verdadeiro goodwill somente surgirá se os ativos e passivos das entidades adquiridas forem reavaliados 


\section{cálculo da viabilidade econômica ao longo do tempo futuro apreciam, sobretudo:}

por algum tipo de valor de mercado. Caso contrário, o goodwill será uma mistura de "goodwill puro" e de outras diferenças de avaliação. Por consequinte, goodwill é aquele "algo mais" pago sobre o valor de mercado do patrimônio líquido das entidades adquiridas, devido a uma expectativa (subjetiva) de lucros futuros além de seus custos de oportunidade, resultante da sinergia existente entre os ativos da entidade (SHMIDT; SANTOS, 2002, p. 45). Como bem frisa Martinho Maurício Gomes de Ornelas: A fórmula de cálculo do goodwill leva em conta que é necessário transmitir a seus usuários a visão de que o goodwill ou aviamento corresponde ao efeito sinérgico, ou seja, a avaliação do todo patrimonial pode ser superior à avaliação individual de cada um de seus componentes; corresponde esse efeito à capacidade que a sociedade possui de gerar lucros acima daquele considerado normal; tem, portanto, caráter de algo mais, do plus, do sobre valor. (ORNELAS, 2001, p. 146). Conforme Priscila Maria Pereira Corrêa da Fonseca: “[...] a aferição do goodwill apresenta determinadas conotações que, com freqüência, dificultam a tarefa do Expert. É que, como já se relevou, em geral impende preliminarmente apurar o valor global da empresa para, só aí então, encontrar o valor correspondente àquele sobre valor. Nesse sentido, o valor final encontrado para a empresa pode ser superior à soma daquele atribuído aos ativos individualmente.” (FONSECA, 2007, p. 233). Verifica-se também, pelo estudo da doutrina contábil, que os métodos científicos, econômicos e contábeis, para a mensuração do aviamento ou goodwill são vários. Salienta Antônio Lopes de Sá: "Muitos foram os intelectuais que propuseram fórmulas para o cálculo do aviamento, vários são os que ainda se apresentam. Não existe uniformidade técnica quanto às fórmulas aplicáveis praticamente ao cálculo de "aviamento" e sequer existe consenso sobre uma, inquestionável. As bases teóricas de um modelo qualitativo para conhecer tal valor imaterial, todavia, são uniformemente reconhecidas em doutrina, ou seja, quanto aos fatores a serem considerados. A multiplicidade de critérios referida, defendida pelos seus autores e adeptos, possui valor de tentativa de tradução do fenômeno em linguagem matemática, mas não lograram ainda um reconhecimento universal. Há uma considerável controvérsia sobre os métodos e critérios, e, não obstante a idoneidade de alguns autores que as sugerem, é impossível dizer que sejam as mesmas consagradas a ponto de adotá-las sem condicionantes" (SÂ, 2009, p. 157). Priscila Maria Pereira Corrêa da Fonseca(2007) expõe que: "Há vários e diversificados métodos para avaliação da empresa. Com amparo no lucro verificado, são inúmeras as fórmulas sistematizadas pelos experts para o cálculo do goodwill. Aquela mais comumente empregada é a seguinte: FC=RLm [(1+i)3] : [(1+i)3], em que FC = fundo de comércio, cujo valor pretende-se determinar, igual aos resultados líquidos dos anos seguintes, devidamente capitalizados e transpostos à época periciada; $\mathrm{RLm}=$ resultado líquido médio convertido pelos índices constantes da Tabela Prática para Cálculo de Atualização Monetária dos Débitos Judiciais; 3 = número de ciclos futuros, representado em anos, o qual poderá variar de caso a caso. O fator temporal utilizado é estimado, normalmente, em duas ou três vezes o lucro líquido verificado nos últimos 3 ou 5 anos. (FONSECA, 2007, p. 231). Ao citar Manobe, a mesma respeitável Priscila Maria Pereira Corrêa da Fonseca expõe: "Massanori Manobe, por seu turno, considera o lucro líquido e determinado fator multiplicativo para obtenção do goodwill: $\mathrm{G}=[\mathrm{LL}-\mathrm{RA}$ - (i. AT)].F. Na referida fórmula: $\mathrm{G}=$ valor do goodwill; $\mathrm{LL}=$ lucro líquido; RA = remuneração da administração; $\mathrm{i}=$ taxa de juros aplicável ao capital imobilizado em ativos tangíveis; $\mathrm{AT}$ = ativos tangíveis; $\mathrm{F}$ = fator multiplicativo para a obtenção do goodwill. A fórmula supra tem outra variante, usualmente denominada Método de Nova Iorque, na qual se utilizam os lucros líquidos médios dos últimos cinco anos: $G=$ [LLM - RA - (I.AT)].F em que: $\mathrm{G}=$ valor do goodwill; $\mathrm{LLM}=$ lucro líquido médio dos últimos cinco anos; RA = remuneração da administração; $\mathrm{i}=$ taxa de juros aplicável ao capital imobilizado em ativos tangíveis; AT = ativos tangíveis; $\mathrm{F}=$ multiplicativo para obtenção do goodwill. (FONSECA, 2007, p. 232). O doutrinador contábil Martinho Maurício Gomes de Ornelas acresce que: “A terceira fórmula, conhecida como HATFIELD, introduz a visão do goodwill como resíduo em relação aos outros ativos: $G=[(\mathrm{LL}-\mathrm{RA}) / \mathrm{j}]-\mathrm{AT}$, onde $\mathrm{G}=$ valor do goodwill, $\mathrm{LL}=$ lucro líquido médio dos últimos cinco anos, $\mathrm{RA}=$ remuneração da administração, $\mathrm{j}=$ taxa de capitalização dos juros, AT = ativos tangíveis" (ORNELAS, 2001, p. 137). Para análise eminentemente contábil das diversas fórmulas de mensuração do aviamento vide, na literatura especializada contabilista, as respectivas derivações e os denominados Métodos de Nova Iorque e Hatfield em: Ornelas (2001. p. 136- 146). Sobre outros métodos, ver também: Hoog (2011, p. 156-166). E, além dos Métodos de Nova Iorque e Hatfield, vide o Método de Lawrence R. Dicksee; Método do Valor Atual dos Superlucros; Método de Custo de Reposição ou Custo Corrente; Método do Valor Econômico e o Método do Valor de Realização em: Paulo 
resultados passados, para projeção de fluxos de caixa futuros; intervalos de tempo, passados e futuros; taxas de juros e de risco, custos de capital, utilizados para se descontarem os valores futuros em relação ao valor presente; taxas de crescimento dos resultados sociais.

Conforme exposto em item anterior, ${ }^{43}$ diante da aludida assimetria de informações, os credores jamais saberão, a não ser com alto custo, se o valor oferecido no plano é superior ou inferior ao da hipótese de liquidação. Percebese também que a falta de critérios de avaliação econômica impede ao Juiz de adequadamente fundamentar sua decisão pela concessão da recuperação, em sobreposição à decisão tomada pelos credores em assembléia. As omissões legislativas em relação ao requisito de validação econômica, juntamente com a omissão quanto à informação completa em relação ao valor da empresa, fazem com que a validação econômica não seja regra de decisões, bem como não faz exigir mecanismo imparcial e idôneo de mensuração do valor da atividade.

\section{CONCLUSÃO}

Evidentemente, não se pretendeu esgotar o tema. O que se buscou foi fazer um trabalho eminentemente construtivo, de caráter acadêmico e reflexivo. Verifica-se que o atual contexto social e econômico de nosso país, por si, já impõe severas adversidades ao sucesso do empresário quando do exercício de sua atividade, tais como alta carga tributária, concorrência antiética e ônus advindos da legislação do trabalho. O tema objeto deste trabalho se justifica, dada a sua cada vez maior presença no dia a dia do empresário. A princípio, traria a Lei 11.101/05 novo remédio destinado a viabilizar a superação da crise, mediante melhor negociação entre credores e devedor empresário, de modo a se evitar a declaração de falência. Sabe-se que quanto maiores, numerosas, contínuas, duradouras e tranquilo for o exercício das atividades econômicas, maior será o fomento para a dinamização da economia de nosso país, com geração de mais empregos, recolhimento de mais tributos e acumulação de mais parceiros comerciais.

O tema é de suma importância e merece ser verdadeiramente considerado, por empresários, empresas, sócios e todos aqueles cujos interesses sociais e econômicos gravitam sobre a atividade de natureza empresária. Dados empíricos e quantitativos, de credibilidade, evidenciam a necessidade de

Schmidt e José Luiz dos Santos (2002, p. 51-55). Quanto ao Calculo de M; além os denominados Métodos de M. Leake; Método de Schmalenbach; Método de Auler; Método de Gref; Método de Retail; Método de Triendlander; Método Clássico Inglês; Método de Schonwandt; Método de Gustav Muller; Método de Manfredo Berliner; Método de Avaliação sem Escrita Regular e Método Clássico, ver LuizAutuori (1969. p. 127-188).

43 Foi mencionado em item anterior que o credor, que pretenda fundamentar sua eventual objeção ao plano de recuperação, terá de elaborar, por conta própria, análise e auditoria quanto aos documentos apresentados, transformando-se em mais custos, os quais serão somados ao crédito existente que não foi recebido ainda. 
aperfeiçoamento da lei 11.101/05. De fato, identifica-se que o percentual de atividades que pleiteam judicialmente a recuperação, que obtenham sucesso, e se reestabelecem no mercado, é extremamente baixo e inadequado.

Portanto, como hipótese de resposta ao problema deste trabalho, podese inferir que devem ser alterados os dispositivos da lei 11.101/05, de modo a proporcionar meio procedimental adequado para completa informação e cognição dos credores, evitando assimetria de informações, como, por exemplo, ao não impor ao administrador judicial o dever de produzir relatório circunstanciado sobre a verdadeira situação do devedor em momento anterior à ocorrência de assembleia de geral de credores, com o objetivo de aceitar, rejeitar ou modificar o plano de recuperação.

No mesmo sentido, devem ser ajustados dispositivos para obter-se maior eficiência, de modo que seja apresentado à assembleia geral de credores documento confeccionado que contenha um relatório detalhado, feito por pessoa imparcial e totalmente desvinculada da administração e gerência do devedor, que tenha total acesso ao dia a dia da atividade, livros, estabelecimento e qualquer documento.

Ademais, devem ser ajustados dispositivos na Lei 11.101/05 para que hajam regras próprias para verificação do verdadeiro grau e estado de atividades negociais de quem está em crise. Também, devem ser ajustados dispositivos na Lei 11.101/05 para que se imponha a necessidade de elaboração de um relatório circunstanciado feito pelo administrador judicial, ou qualquer outro documento idôneo, sem favorecimentos ou parcialidades, que disponibilizasse a todos os credores as informações indispensáveis às deliberações relacionadas ao destino do devedor.

No mesmo sentido, também, devem ser ajustados dispositivos na Lei 11.101/05 para seja imperiosa à necessidade de se relacionar quais seriam os créditos não submetidos à recuperação, bem como se exija a juntada de certidões de débitos perante as Fazendas Públicas, pois até o momento, não existem tais exigências nos artigos 51 e 53 da referida lei.

Acredita-se, que desta forma, será possível viabilizar, de forma adequada e desejada, a superação da situação de crise econômico-financeira do devedor, a fim de permitir a manutenção da fonte produtora, do emprego dos trabalhadores e dos interesses dos credores, promovendo, assim, a preservação da empresa, sua função social e o estímulo à atividade econômica. 


\section{REFERÊNCIAS}

ABRAÃO, Nelson. Curso de direito falimentar. 5. ed. São Paulo: LEUD, 1997.

ABRÃO, Carlos Henrique. Comentários aos arts. 70 ao 104. In: ABRÃO, Carlos Henrique; TOLEDO, Paulo F. C. Salles de (Coord.). Comentário à lei de recuperação de empresas e falência. 3. ed. São Paulo: Saraiva, 2009.

AMARAL NETO, Francisco dos Santos. Direito civil: introdução. 5. ed. Rio de Janeiro: Renovar, 2003.

BANDO, JanainaRossarolla. Da possibilidade jurídica de recuperação judicial do produtor rural. Revista de Direito Empresarial, Belo Horizonte, ano 11, n. 1, p. 239-253, jan./abr. 2014.

BRAGA. Tribunal da Comarca de Contas. Relatório da administradora da insolvência (art. ${ }^{\circ}$ 155. $^{\circ}$ CIRE. Processo n. ${ }^{\circ}$ 271/14.5TBAMR, V. N. Famalicão, Instância Central - Secção de Comércio. Elaborado por Deolinda Ribas e Paulo Manuel Macedo de Barros - NIF/NIPC: 175620113. 22 out. 2014. Disponível em: <http://n-insolvencias.com/sites/ninsolvencias/files/ insolvencias_1414159866/2494_Relatorio_Art155.pdf >. Acesso em: 10 ago. 2016.

BRASIL. Constituição da República Federativa do Brasil de 1988. Brasília: Senado, 1988. Nós, representantes do povo brasileiro, reunidos em Assembléia Nacional Constituinte para instituir um Estado Democrático, destinado a assegurar o exercício dos direitos sociais e individuais, a liberdade, a segurança, o bem-estar, o desenvolvimento, a igualdade e a justiça (...). Diário Oficial da União, Brasília, 5 out. 1988. Disponível em: < http://www.planalto.gov.br/ ccivil_03/Constituicao/Constituicao.htm>. Acesso em: 15 set. 2016.

BRASIL. Decreto-Lei no 7.661 de 21 jun. de 1945. Lei de Falências. Diário Oficial da União, Rio de Janeiro, 21 jun. 1945. Disponível em: <http://www. planalto.gov.br/ ccivil_03/decreto-lei/Del7661.htm>. Acesso em: 02 fev. 2015.

BRASIL. Lei n ${ }^{\circ} 10.406$, de 10 de janeiro de 2002. Institui o Código Civil. Diário Oficial da União. Brasília, 11 jan. 2002a. Disponível em: <http://www.planalto. gov.br/ccivil_03 /LEIS/2002/L10406.htm>. Acesso em: 03 out. 2015.

BRASIL. Lei n ${ }^{\circ} 11.101$, de 9 de fevereiro de 2005.Regula a recuperação judicial, a extrajudicial e a falência do empresário e da sociedade empresária. Diário Oficial da União, Brasília, 09 fev. 2005. Disponível em: <http://www.planalto. gov.br/ccivil_03/_ato2004-2006/2005/lei/111101.htm>. Acesso em: 02 de fev. 2015.

BRASIL. Superior Tribunal de Justiça.Consulta processual. Brasília: STJ, 2016. Disponível em: <http://www.stj.jus.br/sites/STJ/default/pt_BR/Processos/ Consulta-Processual>. Acesso em: 10 jun. 2016. 
BRASIL. Superior Tribunal de Justiça. AgRg no CC 110.250/DF, Rel. Min. Nancy Andrighi. Diário de Justiça Eletrônico, Brasília, 2010a. Disponível em: $<$ http://www.stj.jus.br/SCON/ jurisprudencia/doc.jsp?livre=110250\&b=ACOR $\& p=$ true $\& l=10 \& i=9$ >. Acesso em: 10 jun. 2015.

BRASIL. Superior Tribunal de Justiça. Agravo Regimental 111.614/DF. Relatora: Ministra Nancy Andrighi, Segunda Seção. Diário de Justiça Eletrônico, Brasília, 2010b. Disponível em: <https://stj.jusbrasil.com.br/jurisprudencia/17551964/ agravo-regimental-no-conflito-de-competencia-agrg-no-cc-111614-df-20100072357-6-stj/relatorio-e-voto-1755196>. Acesso em: 10 jun. 2015.

BRASIL. Superior Tribunal de Justiça. Agravo Regimental na Medida Cautelar23.499/RS. Relator: MinistroHumberto Martins-Segunda Turma. Diário de Justiça Eletrônico, Brasília, 19dez. 2014c. Disponível em: <http:// www.stj.jus.br/SCON/jurisprudencia/toc .jsp?livre=\%28\%22HUMBERTO+M ARTINS $\% 22 \% 29 . \mathrm{min} . \&$ processo=23499\& \& $\mathrm{b}=\mathrm{ACOR} \&$ thesaurus=JURIDIC O\&p=true > . Acesso em: 20 jun. 2015.

BRASIL. Superior Tribunal de Justiça. Conflito de Competência101.552/AL. Relator: Desembargador Convocado Honildo Amaral de Mello Castro. Diário de Justiça Eletrônico, Brasília, 01 out.2009.Disponível em: <http://www.stj.jus. $\mathrm{br} / \mathrm{SCON} /$ jurisprudencia/toc.jsp?livre $=\% 28 \% 22 \mathrm{HONILDO}+\mathrm{AMARAL}+\mathrm{DE}+$ $\mathrm{MELLO}+\mathrm{CASTRO}+\% 28 \mathrm{DESEMBARGADOR}+\mathrm{CONVOCADO}+\mathrm{DO}+\mathrm{TJ} \% 2 \mathrm{~F}$ AP\% 29\%22\%29.min. \&processo $=101552 \& \& b=A C O R \&$ thesaurus=JURIDIC O\&p=true>. Acesso em: 10 jun. 2015.

BRASIL. Superior Tribunal de Justiça. Conflito de Competência116.696/ DF. Relatora: Ministra Nancy Andrigh, Segunda Seção. Diário de Justiça Eletrônico, Brasília, 31 ago. 2011.Disponível em: <http://www.stj.jus.br/SCON/ jurisprudencia/toc. jsp?livre $=\% 28 \% 22 \mathrm{NANCY}+\mathrm{ANDRIGHI} \% 22 \% 29 . \mathrm{min} . \&$ processo $=116696 \& \& b=A C O R \&$ thesaurus $=J U R I D I C O \& p=$ true $>$. Acesso em: 10 jun. 2015.

BRASIL. Superior Tribunal de Justiça. Reclamação 18.538/PA. Relator: Ministro Antonio Carlos Ferreira - Segunda Seção. Diário de Justiça Eletrônico, Brasília, 06 out.2014. Disponível em: <http://www.stj.jus.br/SCON/jurisprudencia/ toc. jsp?livre $=\% 28 \% 22$ ANTONIO+CARLOS+FERREIRA $\% 22 \% 29$. min. \&proces so $=18538 \& \& b=A C O R \&$ thesaurus $=J U R I D I C O \& p=$ true $>$. Acesso em: 10 jun. 2015.

BRASIL. Superior Tribunal de Justiça. Recurso Especial1173735/RN. Relator: MinistroLuis Felipe Salomão-Quarta Turma. Diário de Justiça Eletrônico, Brasília, 09maio2014d. Disponível em: <http:/www.stj.jus.br/ SCON/jurisprudencia/ toc.jsp?livre $=\% 28 \% 22 \mathrm{LUIS}+\mathrm{FELIPE}+\mathrm{SALOM} \% \mathrm{C}$ $3 \mathrm{O} \% 22 \% 29 . \mathrm{min} . \&$ processo $=1173735 \& \& \mathrm{~b}=\mathrm{ACOR} \&$ thesaurus=JURIDICO $\& p=$ true $>$. Acesso em: 20 jun. 2015. 
BRASIL. Superior Tribunal de Justiça. Recurso Especial 1187404/MT. Relator: MinistroLuis Felipe Salomão-Corte Especial. Diário de Justiça Eletrônico, Brasília, 21ago. 2013f. Disponível em: <http://www.stj.jus.br/ SCON/jurisprudencia/toc.jsp?livre $=\% 28 \% 22$ LUIS +FELIPE+SALOM $\%$ C $3 \mathrm{O} \% 22 \% 29 . \mathrm{min} . \&$ processo $=1187404 \& \& \mathrm{~b}=\mathrm{ACOR} \&$ thesaurus=JURIDICO $\& p=$ true $>$. Acesso em: 20 jun. 2015.

BRASIL. Superior Tribunal de Justiça. Recurso Especial 1263500/ES. Relatora: Ministra Maria Isabel Gallotti - Quarta Turma. Diário de Justiça Eletrônico, Brasília, 12 abr. 2013b. Disponível em: <http:/www.stj.jus.br/ SCON/jurisprudencia/toc.jsp? livre $=\% 28 \% 22 \mathrm{MARIA+ISABEL+GALLOT}$ $\mathrm{TI} \% 22 \% 29 . \mathrm{min} . \&$ processo $=1263500 \& \& \mathrm{~b}=\mathrm{ACOR} \&$ thesaurus=JURIDICO $\&$ $\mathrm{p}=$ true $>$. Acesso em: 10 jun. 2015.

BRASIL. Superior Tribunal de Justiça. Recurso Especial 1279525/PA. Relator: MinistroRicardo Villas BôasCueva - Terceira Turma. Diário de Justiça Eletrônico, Brasília, 13mar.2013g. Disponível em: <http://www.stj.jus.br/ SCON/jurisprudencia/ toc.jsp?livre $=\% 28 \% 22$ RICARDO+VILLAS+B $\%$ D4AS+ CUEVA \% 22\% 29.min. \&processo $=1279525 \& \& \mathrm{~b}=$ ACOR \& thesaurus=JURIDI CO\&p=true $>$. Acesso em: 25 jun. 2015.

BRASIL. Superior Tribunal de Justiça. Recurso Especial 1314209/SP. Relatora: MinistraNancyAndrighi - Terceira Turma. Diário de Justiça Eletrônico, Brasília, 01jun.2012e. Disponível em: <http://www.stj.jus.br/SCON/jurisprudencia/toc. jsp? livre $=\% 28 \% 22 \mathrm{NANCY}+\mathrm{ANDRIGHI} \% 22 \% 29 . \mathrm{min}$. \& processo $=1314209$ $\& \& b=A C O R \&$ thesaurus=JURIDICO\&p=true $>$. Acesso em: 12 jul. 2015.

BRASIL. Supremo Tribunal Federal. Ação Direta de Inconstitucionalidade3934. Relator: MinistroRicardo Lewandowski. Diário de Justiça Eletrônico, Brasília, 30març.2011. Disponível em: <http://www.stf.jus.br/portal/jurisprudencia/ listar Jurisprudencia.asp?s1=\%28\%283934\%2ENUME\%2E+OU+3934\%2E DMS \%2E\%29\%28\%28RICARDO+LEWANDOWSKI\%29\%2ENORL\%2E+ OU+\%28RICARDO+LEWANDOWSKI $\% 29 \% 2$ ENPRO $\% 2 \mathrm{E}+\mathrm{OU}+\% 28 \mathrm{RICA}$ RDO+LEWANDOWSKI\%29\%2EDMS $\% 2 \mathrm{E} \% 29 \% 29+\mathrm{NAO}+\mathrm{S} \% 2 \mathrm{EPRES} \% 2$ E\&base=baseMonocraticas\&url=http://tinyurl.com/h2n792r $>$. Acesso em: 20 jun. 2015.

BERGER, Dora. A insolvência no Brasil e na Alemanha. Porto Alegre: Sergio Antonio Fabris, 2001.

BUTTWILL,Klas; WIHLBORG, Clas. The efficiency of the bankruptcy process:an international comparison.[S. 1.]: Ratio,2004. Disponível em: http:// ratio.se/publikationer/working-paper-65-efficiency-bankruptcy-processinternational-comparison/ . Acesso em 15.09.2016.

CALEIRO, João Pedro. 10 números que revelam a escala da crise econômica no Brasil. Exame, São Paulo, ano 50, n. 6, ed. 1110, mar. 2016. Disponível 
em: <http://exame.abril.com.br/economia/frases-e-numeros/10-numeros-querevelam-a-escala-da-crise-economica-no-brasil>. Acesso em: 11 out. 2016.

CAMPINHO, Sérgio. Falência e recuperação de empresa: o nome regime da insolvência empresarial. 5. ed. Rio de Janeiro: Renovar, 2010.

CAVALLI, Cássio.Reflexões sobre a recuperação judicial: uma análise da aferição da viabilidade econômica como pressuposto para o deferimento do processamento da recuperação judicial.In: MENDES, Bernardo Bicalho de Alvarenga. (Org.). Aspectos polêmicos e atuais da Lei de recuperação de empresas. Belo Horizonte: Editora D’ Plácido, 2016. p. 1303-1331.

CAVALLI, Cassio. A dispensa de CND para concessão da recuperação judicial após a lei 13.043/14. [S. 1.]: Do Autor, 2016.Disponível em http://www. cassiocavalli.com.br/?p=494. Acesso em: 25 out. 16 .

COELHO, Fábio Ulhoa. Comentários à lei de falências e de recuperação de empresas. 9. São Paulo: Saraiva, 2013.

COELHO, Fábio Ulhôa. Curso de direito comercial. 8.ed. São Paulo: Saraiva, 2005. v.2.

COMPARATO, Fabio Konder. Estado, Empresa e Função Social. São Paulo: RT, 1996. p. 38-46.

GONÇALVES NETO, Alfredo de Assis. Direito de empresa. São Paulo: Revista dos Tribunais, 2007.

DUARTE, Henrique Vaz. Questões sobre recuperação e falência. 2. ed. Coimbra: Almedina 2004.

DUARTE. Ronnie Preuss. Teoria da empresa à luz do novo código civil Brasileiro. São Paulo: Método, 2004.

ESPANHA. Ley 22/2003, de 9 de julio, Concursal. BoletínOficial del Estado, n. 164, 10 julio 2003, p. 26905; 26965. Disponível em: <https://www.boe.es/ buscar/act.php?id=BOE-A-2003-13813> Acesso em: 17 maio 2017.

FASSI, Santiago C.; GEBHARDT, Marcelo. Concursos y quiebras: comentário exegético de la ley 24.5222: jurisprudenciaapplicable. Buenos Aires: Astrea, 2005.

FONSECA, Priscila Maria Pereira Corrêa da. Dissolução parcial, retirada e exclusão de sócio no Novo Código Civil. 4 ed. São Paulo: Atlas, 2007.

GONÇALVES, Oksandro; ALMENDANHA, Cristina Malaski. Análise econômica do direito e a suspensão das ações e execuções em face da empresa em recuperação judicial: instrumento para o desenvolvimento. Revista de Direito Empresaria. Belo Horizonte, ano 10, n. 2, maio/ago. 2013. Disponível 
em: <http://www.bidforum.com.br/PDI0006.aspx?pdiCntd=96852>. Acesso em: 21 set. 2016 .

GONÇALVEZ NETO, Alfredo de Assis. Lições de direito societário. 2. ed. São Paulo: Juarez de Oliveira, 2004.

GUIMARÃES, BernardoStrobel; BORDA, Daniel Siqueira. Limites e possibilidades de empresas em recuperação judicial participarem de licitações públicas (Ecos do acórdão proferido pelo Superior Tribunal de Justiça no AgRg na Medida Cautelar 23.499/RS). Revista de Direito Empresarial- RDEmp, Belo Horizonte, ano 12, n. 1, p. 257-279, jan./abr. 2015.

GUIMARÃES, Márcio Souza. A intervenção do Ministério Público no Direito Falimentar e de Recuperação de Empresas: 10 anos de experiência na Lei 11.101/05. In: MENDES, Bernardo Bicalho de Alvarenga. (Org.). Aspectos polêmicos e atuais da Lei de recuperação de empresas. Belo Horizonte: Editora D’ Plácido, 2016. p. 473-497.

GUIMARÃES, Maria Celeste Morais. Entraves à eficácia da Lei de recuperação de empresas em crise. Como superá-los?Revista da Faculdade de Direito da UFMG, Belo Horizonte, n. 50, p. 265-280, jan./ jul. 2007a.

GUIMARÃES, Maria Celeste Morais. Recuperação judicial de empresas. Belo Horizonte: Del Rey, 2007b. p. 105-109.

LACERDA, José Cândido Sampaio de. Manual de direito falimentar. 14. ed. Rio de Janeiro: Freitas Bastos, 1999.

LANA, Henrique Avelino Rodrigues de Paula. Dissolução parcial nas sociedades limitadas: considerações acerca do momento para apuração dos haveres do sócio retirante. Revista Magister de Direito Empresarial Concorrencial e do Consumidor, Porto Alegre, v.5, n.26, , p.10-16, abr. 2009.

LANA, Henrique Avelino Rodrigues de Paula; PIMENTA, Eduardo Goulart. Notável relação entre análise econômica do direito e os direitos de propriedade. Belo Horizonte: PUC Minas, 2010. Disponível em: <http://www.fmd.pucminas. br/Virtuajus/2_ 2010/discentes/NOTAVEL \%20RELACAO \%20ENTRE $\% 20$ ANALISE \% 20ECONOMICA \% 20DO \% 20DIREITO \%20E \% 20OS \% 20 DIREITOS\%20DE\%20PROPRIEDADE.pdf > Acesso em: 14 jul. 2016.

LEITÃO, Luís Manoel Teles de Menezes. Código de insolvência e da recuperação de empresas anotado.2. ed. Coimbra: Almedina, 2005.

LOBATO, Moacyr de Campos Filho. A recuperação judicial, a falência e o futuro. In: MENDES, Bernardo Bicalho de Alvarenga. (Org.). Aspectos polêmicos e atuais da Lei de recuperação de empresas. Belo Horizonte: Editora D’ Plácido, 2016. p. 665-674. 
LOPES, Ana Frazão de Azevedo. Empresa e propriedade: função social e abuso de poder econômico. São Paulo: QuartierLatin, 2006. p. 119.

LOPES, Braulio Lisboa. Aspectos tributários da falência de recuperação de empresas. São Paulo: 2008.

LOPES, Idevan César Rauen. Empresa e exclusão de sócio: de acordo com o novo código civil. Curitiba: Juruá, 2004.

LUCENA, José Waldecy. Das sociedades limitadas. 4. ed. Rio de Janeiro: Renovar, 2001.

LUCENA, José Waldecy. Das sociedades por quotas de responsabilidade limitada. Rio de Janeiro: Renovar, 1996

MAGALHÃES, Rodrigo Almeida. A empresa em crise. Virtuajus Revista Eletrônica da Faculdade Mineira de Direito, v. 1, p. 1-12, 2008.

MAGALHÃES, Rodrigo Almeida. A função social da empresa. Revista Magister de Direito Empresarial Concorrencial e do Consumidor, Porto Alegre, v.5, n.28 , p.5-12, ago. 2009.

MAGALHÃES, Rodrigo Almeida; FERREIRA, S. A. O direito de empresa em crise. Revista Forense, v. 398, p. 211-228, 2008.

MANKIW, N. Gregory. Introdução à economia. 3. ed. Tradução de Allan Vidigal Hastings. São Paulo: Cengage Learning, 2009a.

MANKIW, N. Gregory. Princípios de microeconomia. (Tradução deAllan Vidigal Hastings. São Paulo: Cengage Learning, 2009b.

MENDONÇA, José XavierCarvalho de. Tratado de direito comercial brasileiro. 6. ed. São Paulo: Freitas Bastos, 1964. p. 14-15. v.3.

MENDONÇA, José Xavier Carvalho de.Tratado de Direito Comercial Brasileiro. Atualizado por AchilesBevilaqua e Roberto de Carvalho Mendonça. 5. ed. Rio de Janeiro: Freitas Bastos, 1955. v.8.

NEGRÃO, Ricardo. A eficiência do processo judicial na recuperação de empresa. São Paulo: Editora Saraiva, 2010.

NEGRÃO, Ricardo. Manual de direito comercial e de empresa: recuperação de empresas e falência.São Paulo: Saraiva, 2012. v. 3.

PEREIRA, Henrique Viana; MAGALHÃES, Rodrigo Almeida. Princípios constitucionais do direito empresarial: a função social da empresa. Curitiba: Editora CRV, 2011.

PIMENTA, Eduardo Goulart. Análise econômica do direito e a regulamentação das sociedades empresárias brasileiras: entre a autonomia da vontade e a estrita 
legalidade. Revista de Direito Mercantil Industrial, Econômico e Financeiro. Belo Horizonte, v. 142, p. 66-79, 2007a.

PIMENTA, Eduardo Goulart. Direito, economia e relações patrimoniais privadas. Revista de Informação Legislativa, Brasília, v. 43, n. 170, p. 159-174, 2006a.

PIMENTA, Eduardo Goulart. O princípio da preservação da empresa sob a ótica da Constituição Federal e do Código Civil de 2002. Revista do Curso de Direito (Nova Lima), Belo Horizonte, v. 3, p. 75-852004c

PIMENTA, Eduardo Goulart. Recuperação de empresas: um estudo sistematizado. São Paulo: IOB Thomson, 2006b.

PIMENTA, Eduardo Goulart. Recuperação judicial de empresas: caracterização, avanços e limites. Revista Direito GV. São Paulo, v. 2, n. 1, p. 151-166, 2006c.

PORTUGAL. Ministério Público. DL n. ${ }^{\circ}$ 53/2004, de 18 de Março

Código da Insolvência e da Recuperação de Empresas. Lisboa: PGDL, 2004. Disponível em: < http://www.pgdlisboa.pt/leis/lei_mostra_articulado. php?nid=85\&tabela=leis $>$ Acesso em: 05 out. 2011.

PUGLIESI, Adriana Valéria. Direito falimentar e preservação da empresa. São Paulo: QuartierLatin, 2013.

SALAMA, Bruno Meyerhof. O que é pesquisa em direito e economia?Cadernos Direito GV. São Paulo, v. 5, n. 2, mar. 2008. p. 4-55.

SERASA EXPERIAN. Falências e recuperações: recuperações judiciais batem recorde histórico em 2016, revela Serasa Experian. [S. 1.]: Serasaexperian, 2017. Disponível em: <http://noticias.serasaexperian.com.br/blog/2017/01/03/ recuperacoes-judiciais-batem-recorde-historico-em-2016-revela-serasaexperian/> Acesso em: 22 maio. 2016.

SERASA CONSUMIDOR. Serasa Experian é pioneira na adesão à nova cadeia V5 do certificado digital. [S. 1.]: Serasaexperian, 2016. Disponível em: <http:// noticias.serasaexperian.com.br/blog/2016/06/24/serasa-experian-e-pioneirana-adesao-a-nova-cadeia-v5-do-certificado-digital/> Acesso em: 22 maio. 2016.

SMITH, Adam. Uma investigação sobre a natureza e causa das riquezas das nações. São Paulo: Hemus, 2003.

SMITH, David C.; STRÖMBERG,Per. Maximizing the value of distressed assets: Bankruptcy law and the efficient reorganization of firms. [S.1.]: Researchate, 2003. Disponível em: https://www.researchgate.net/publication/228348296_ Maximizing_the_value_of_distressed_assets_Bankruptcy_law_and_the_ efficient_reorganization_of_firms. Acesso em: 30 ago. 2016. 
SONAGLI, Joseliane; GONÇALVES, Oksandro. A (i)legitimidade da cláusula resolutória e a função socioeconômica do procedimento falimentar. Belo Horizonte,Revista de Direito Empresarial-RDEmp, ano 11, n. 2, p. 203-223, maio/ago. 2014.

SOUZAJÚNIOR, Francisco Satiro. Da recuperação extrajudicial. In: SOUZA JÚNIOR, Francisco Satiro de; PITOMBO, Antônio Sérgio. (Org.). Comentários à nova lei de falência e recuperação judicial. São Paulo: Revista dos Tribunais, 2006.

SOUZA JÚNIOR, FrancisoSatiro. Dissolução de sociedades anônimas. In: FINKELSTEIN, Maria Eugênia Reis; PROENÇA, José Marcelo Martins. (Coord.).Direito societário: gestão e controle. São Paulo : Saraiva, 2008. p. 155.

WAISBERG, Ivo. 10 anos da recuperação judicial: sugestões para reforma legislativa.

In: SZTAJN, Rachel; SALLES, Marcos Paulo de Almeida; TEIXEIRA, Tarcisio (Coord.). Direito empresarial: estudos em homenagem ao professor Haroldo Malheiros Duclerc Verçosa. São Paulo, SP: IASP, 2015. p. 340-353.

WHITE, Michelle J. Bankruptcy Law. Handbook of law and economics. London: Elsevier, 2007. p. 17. Disponível em: <http://econweb.ucsd.edu/ miwhite/ Handbook-proofs.pdf > Acesso em: 10 set. 2016.

Recebido em: 15/04/2019. Aprovado em: 19/06/2019. 